\title{
Growth inhibitory and chemo-sensitization effects of naringenin, a natural flavanone purified from Thymus vulgaris, on human breast and colorectal cancer
}

Mohamed Salah I Abaza ${ }^{1 *}$, Khaled Y Orabi ${ }^{2}$, Ebtehal Al-Quattan ${ }^{1}$ and Raja'a J Al-Attiyah ${ }^{3}$

\begin{abstract}
Background: Natural products with diverse bioactivities are becoming an important source of novel agents with medicinal potential. Cancer is a devastating disease that causes the death of millions of people each year. Thus, intense research has been conducted on several natural products to develop novel anticancer drugs.

Methods: Chromatographic and spectral techniques were used for the isolation and identification of naringenin (Nar). MTT, flow cytometry, western blotting, Real Time PCR were used to test anticancer and chemosensitizing effects of Nar, cell cycle, apoptosis, and expression of cell cycle, apoptosis, pro-survival and anti-survival-related genes.
\end{abstract}

Results: In the present study, Thymus vulgaris ethanol extract was purified repeatedly to produce several compounds including the known flavanone, Nar which was identified using different spectral techniques. Nar was shown to inhibit both human colorectal and breast cancer cell growth in a dose- and time-dependent manner through cell cycle arrest at $\mathrm{S}$ - and $\mathrm{G}_{2} / \mathrm{M}$-phases accompanied by an increase in apoptotic cell death. Additionally, Nar altered the expression of apoptosis and cell-cycle regulatory genes by down-regulating $C d k 4, C d k 6, C d k 7, B C \mid 2, x-I A P$ and $C-I A P-2$ and up-regulating p18, p19, p21, caspases 3, 7, 8 and 9, Bak, AIF and Bax in both colorectal and breast cancer cells. Conversely, it diminished the expression levels of the cell survival factors PI3K, pAkt, plkBa and NFkBp65. Moreover, Nar enhanced the sensitivity of colorectal and breast cancer cells to DNA-acting drugs.

Discussion: These findings provide evidence that Nar's pro-apoptotic and chemo-sensitizing effects are mediated by perturbation of cell cycle, upregulation of pro-apoptotic genes and down-regulation of anti-apoptotic genes and inhibition of pro-survival signaling pathways.

Conclusion: In conclusion, Nar might be a promising candidate for chemoprevention and/or chemotherapy of human cancers. However, further studies exploring this therapeutic strategy are necessary.

Keywords: Naringenin, Colorectal and breast cancers, Anticancer effects, Chemo-sensitization, Molecular mechanisms

\footnotetext{
* Correspondence: mohammed.abaza@KU.EDU.KW

${ }^{1}$ Molecular Biology Program, Department of Biological Sciences, Faculty of

Science, Kuwait University, Safat 13060, Kuwait

Full list of author information is available at the end of the article
} 


\section{Background}

Cancer is the leading cause of death in economically developed countries and the second leading cause of death in developing countries [1]. The burden of cancer is increasing in economically developed countries as a result of population aging and growth and, increasingly, an adoption of cancer-associated lifestyle choices, such as smoking, physical inactivity, and unhealthy food.

Colorectal cancer is the third most commonly diagnosed cancer in males and the second in females, with over 1.2 million new cancer cases and 608,700 deaths estimated to have occurred in 2008 [2]. Breast cancer is the most frequently diagnosed cancer and the leading cause of cancer death in females worldwide, accounting for $23 \%$ (1.38 million) of the total new cancer cases and $14 \%(458,400)$ of the total cancer deaths in 2008 [2].

Cancer is the second most common cause of death in Kuwait after cardiovascular diseases [3]. It has been noted that the age-adjusted incidence rates (AAIR) of colorectal cancer among Kuwaiti males has increased by approximately 5-fold over the last 33 years and ranked the most frequent site for the years 2003-2007. For Kuwaiti females, breast cancer has the highest incidence among the Kuwaiti population; breast cancer incidence has increased by 3 -fold over the last 33 years. Conversely, the incidence of colorectal cancer has increased by approximately 4-fold. [3].

Cancer survival rates tend to be poorer in developing countries, most likely because of a combination of a late diagnosis and limited access to timely and standard treatment. Cancer can be treated by chemotherapy, radiation, surgery, monoclonal antibody therapy, and other methods. However, the effectiveness of chemotherapy is often limited by their serious side effects [4]. Radiation may also affect normal tissues. Therefore, complete removal of cancerous tissue without affecting normal tissue is the major goal of treatment. Approximately $50-60 \%$ of cancer patients in the United States utilize agents derived from different parts of plants or nutrients (complementary and alternative medicine), exclusively or concurrently with a traditional therapeutic regimen such as chemotherapy and/or radiation therapy. The need for new drugs has promoted studies evaluating possible anticancer agents in fruits, vegetables, herbs, and spices.

In recent years, dietary phytochemicals have received the attention of various scientists for their action in treating various cancers [5]. Several studies have documented that naturally occurring dietary phytochemicals inhibit the growth of various cancer cells through the inhibition of cell proliferation and the activation of apoptosis [6]. In particular, flavonoids, polyphenolic compounds that occur naturally in the plant kingdom, display a wide range of pharmacological properties, including antioxidant and anti-carcinogenic activities [6-9].
Thyme (Thymus vulgaris L., Family Lamiaceae), which is known in Arabic as "zaatar or "zaitra", is a pleasantsmelling perennial shrub that grows in several regions worldwide [10]. The plant is indigenous to the Mediterranean region and neighboring countries, Northern Africa, and parts of Asia [11]. Thyme is widely used in folk medicine for its expectorant, antitussive, antibronchiolitis, antispasmodic, anthelmintic, carminative and diuretic properties. The aromatic and medicinal properties of the genus Thymus made it one of the most popular plants worldwide. Thymus species have strong antibacterial, antifungal, antiviral, and antioxidant activities [12]. Many pharmacological in vitro studies have revealed the pharmacological activities of both thyme essential oil and plant extracts [13]. Given the various uses of thyme in traditional medicine and the hypothesis that it may have anticancer activity, the present study was undertaken to fractionate Thymus vulgarus in a bioactivity-guided manner, to isolate and identify the bioactive lead(s) that suppress(es) colorectal and breast cancer cell growth, and to study the underlying intracellular signal transduction pathways involved in regulating cell cycle and apoptosis and its/their ability to potentiate the chemo-sensitivity of colorectal and breast cancer cells to DNA-acting drugs.

\section{Methods}

\section{Cell lines}

Human colorectal cancer cell lines (SW1116 and SW837), human breast cancer cell lines (HTB26, HTB132), and normal human fibroblast cells (CRL1554) were obtained from American Type Culture Collection (ATCC; VA, USA). SW1116, SW837, HTB26 and HTB132 cells were cultured in 90\% Leibovitz's L15 medium supplemented with $10 \%$ heat-inactivated fetal bovine serum and grown at $37^{\circ} \mathrm{C}$ in a non- $\mathrm{CO}_{2}$ incubator. CRL1554 cells were cultured in Eagle minimum essential medium, EMEM (90\%) supplemented with $10 \%$ heat-inactivated fetal bovine serum and grown at $37^{\circ} \mathrm{C}$ in the presence of $5 \% \mathrm{CO}_{2}$ and 95\% ambient air.

\section{Chemicals and reagents}

Trypsin, Leibovitz's L-15 and EMEM medium, fetal bovine serum (FBS), and penicillin/ streptomycin solution $(100 \times)$ were obtained from Mediatech, Inc. (Herndon, VA, USA). An Annexin V-FITC apoptosis detection kit was obtained from BD Hoffmann-La Roche Inc. (Nutley, NJ, USA). A DNA-prep kit was obtained from Beckman \& Coulter (FL, USA). All reagents for RT-PCR and real-time qPCR were obtained from Applied Biosystem (Foster City, CA, USA). Nuclear/cytosol fractionation kit was obtained from BioVision, Inc. (Moutain View, CA, USA). Antibodies against PI3K, phospho-Akt1/2/3 (Ser473), Akt, NFkBp65, pIкB $\alpha$ and $\beta$-actin were purchased 
from Santa Cruz Biotechnology (Santa Cruz, CA and Cambridge, UK). All other reagents were purchased from Sigma Chemicals (St Louis, MO, USA). Plasticware was purchased from Falcon Lab (Franklin Lakes, NJ, USA).

\section{General experimental procedure}

Melting points were determined in open capillary tubes using a Mettler 9100 electrothermal melting point apparatus and were uncorrected. IR spectra were recorded using a JASCO FTIR-4100 spectrophotometer. UV spectra were measured in $\mathrm{MeOH}$ using a UV-160 IPC UV-visible dual-beam spectrophotometer. The ${ }^{1} \mathrm{H}$ and

${ }^{13} \mathrm{C}$ NMR spectra were obtained on a Bruker Advance II $600-\mathrm{MHz}$ spectrometer operating at 600 and $150 \mathrm{MHz}$, respectively. Both ${ }^{1} \mathrm{H}$ and ${ }^{13} \mathrm{C}$ NMR spectra were recorded in methanol- $d_{4}$, and the chemical shift values were expressed in $\delta(\mathrm{ppm})$ relative to the internal standard TMS. For the ${ }^{13} \mathrm{C}$ NMR spectra, spectral editing was determined by DEPT. 2D NMR data were obtained using the standard pulse sequence of the Bruker 600 for COSY, HSQC and HMBC. Low resolution EIMS were obtained using a double-focusing magnetic sector mass spectrometer (GS-MS DFS/Thermo).

\section{Plant material}

Thymus vulgaris was obtained commercially from the local market. Its identity was established as Thymus vulgaris by Dr. KT Mathew of Kuwait University. A voucher specimen was deposited at Kuwait University Herbarium and given the number KTM \& IYQ (5920).

\section{Extraction and isolation}

The dried ground plant $(1.0 \mathrm{~kg})$ was percolated at room temperature with $96 \% \mathrm{EtOH}(1 \mathrm{~L} \times 3)$, and the extract was evaporated in vacuo to leave $43 \mathrm{~g}$ of residue. Part of this crude extract $(10 \mathrm{~g})$ was partitioned between water and ethyl acetate. Part of the ethyl acetate fraction $(2 \mathrm{~g})$ was chromatographed over a Si gel $(190 \mathrm{~g}, 38 \mathrm{~cm} \times 4 \mathrm{~cm})$, using $15 \%$ acetone in chloroform as the eluent, to yield, after crystallization, $5.3 \mathrm{mg}(0.01 \%$ yield $)$ of pure Nar as pale yellow needles. This process was scaled up to yield Nar quantities enough for the study.

\section{Time- and dose-dependent anti-proliferative effects of Nar on human breast and colorectal cancer cells and normal human fibroblast}

Cell viability was measured using MTT assay, which is based on the conversion of MTT to formazan crystals by mitochondrial dehydrogenases [14]. Briefly, human colorectal (SW1116, SW837) and breast (HTB26, HTB132) cancer cell lines and normal human fibroblast cells (CRL1554) were seeded $\left(27 \times 10^{3}\right.$ cells/well $)$ in 96-well plates and incubated in a non- $\mathrm{CO}_{2}$ or $\mathrm{CO}_{2}$ incubator for $18 \mathrm{~h}$, depending on the cancer cell type and medium used.
The cells were then treated with various concentrations of Nar $(0.05-4 \mathrm{mM})$ for 6-24 h. Untreated cells, to which only DMSO was added at a final concentration of $0.2 \%$, were used as a control. MTT solution $(5 \mathrm{mg} / \mathrm{ml}$, filtered) was added to the incubated cells $(20 \mu \mathrm{l} /$ well $)$; the cells were then incubated for another $4 \mathrm{~h}$, and the medium was discarded. DMSO $(200 \mu \mathrm{l})$ was added to each well, and absorbance was measured in a micro-plate reader at a $\lambda 492 \mathrm{~nm}$. The percentages of cell viability and cytotoxicity were calculated using the following equations: \% cell viability $=\left(\mathrm{OD}_{492}\right.$ of treated sample $/ \mathrm{OD}_{492}$ of untreated sample $) \times 100 ; \%$ cytotoxicity $=100-\left(\mathrm{OD}_{492}\right.$ of treated sample/OD 492 of untreated sample) $\times 100)$.

\section{Colony forming assay}

The antiproliferative effects of Nar on human colorectal (SW1116 and SW837) and breast (HTB26 and HTB132) cancer cell lines were confirmed using a colonyformation assay. Briefly, cancer cells $\left(5 \times 10^{5} /\right.$ well $)$ were plated in a 24-well plate and incubated at $37^{\circ} \mathrm{C}$ in a non- $\mathrm{CO}_{2}$ incubator for $24 \mathrm{~h}$. Thereafter, the cells were treated with $\mathrm{Nar}(3 \mathrm{mM})$ and incubated at $37^{\circ} \mathrm{C}$ for $24 \mathrm{~h}$. After that, untreated and treated human cancer cells were collected by trypsinization and washed with Hank's Balanced Salt Solution (HBSS), counted, and plated in 24-well plates at 500 cells/well and incubated at $37^{\circ} \mathrm{C}$ for $10-14$ days. The colonies were washed with cold phosphate-buffered saline (PBS), fixed with $100 \%$ methanol, and stained with $0.5 \%$ crystal violet. The colonies were counted using an inverted microscope. The data are presented as the number of colonies formed with and without treatment.

\section{Cell cycle analysis by flow cytometry}

The distribution of cell-cycle phases $\left(G_{0} / G_{1}, S\right.$, and $\left.G_{2} / M\right)$ was determined using flow cytometry by measuring the DNA content of nuclei labeled with propidium iodide as described previously [15]. Briefly, human colorectal (SW1116 and SW837) and breast (HTB 26 and HTB132) cancer cell lines were plated $\left(5 \times 10^{5}\right.$ cells $\left./ \mathrm{ml}\right)$ in 24 -well plates and incubated at $37^{\circ} \mathrm{C}$ in a non- $\mathrm{CO}_{2}$ incubator for $18 \mathrm{~h}$. The cells were then treated with $\operatorname{Nar}(3 \mathrm{mM})$ for $24 \mathrm{~h}$. Untreated and treated human cancer cells were collected by trypsinization, washed with cold phosphatebuffered saline (PBS) and counted. Cells were processed using a DNA-prep kit (Beckman \& Coulter) and a DNAPrep EPICS workstation (Beckman \& Coulter). During this process, the cells were treated with a cell-membrane permeabilizing agent (non-ionic detergent) followed by propidium iodide (PI) and RNase. The samples were incubated at room temperature for $15 \mathrm{~min}$ before analysis by flow cytometry (FC500, Beckman \& Coulter). The percentages of cells in different cell cycle phases were calculated using the Phoenix statistical software 
package, advanced DNA cell-cycle software (Phoenix Flow System, San Diego, CA).

\section{DNA fragmentation assay}

Induction of apoptosis was monitored using a DNA fragmentation assay [16]. Briefly, human colorectal (SW1116 and SW837) and breast (HTB 26 and HTB 132) cancer cell lines were plated $\left(5 \times 10^{5}\right.$ cells $\left./ \mathrm{ml}\right)$ into 24-well plates and incubated at $37^{\circ} \mathrm{C}$ in non- $\mathrm{CO}_{2}$ incubator for $18 \mathrm{~h}$. Cells were treated with $\operatorname{Nar}(3 \mathrm{mM})$ and then collected by trypsinization, washed with cold phosphate-buffered saline (PBS) and centrifuged (1000x g, $5 \mathrm{~min})$. The cells were then resuspended in $200 \mu \mathrm{l}$ of DNA lysis buffer (10 mM EDTA, 0.5\% Triton X-100, $0.5 \mathrm{mg} / \mathrm{ml}$ proteinase $\mathrm{K}$ and $50 \mathrm{mM}$ Tris $-\mathrm{HCl}, \mathrm{pH}$ 8). The lysate was immediately incubated for $24 \mathrm{~h}$ at $56^{\circ} \mathrm{C}$. After adding phenol/chloroform/isoamyl alcohol (25:24:1) to the lysate, DNA was precipitated with $100 \%$ ethanol. The suspension was centrifuged, and the isolated DNA was dissolved in $100 \mu \mathrm{l}$ of TE buffer. The DNA samples were then loaded onto a $1 \%$ agarose gel containing $0.1 \%$ ethidium bromide and electrophoresed for $2 \mathrm{~h}$ at $70 \mathrm{~V}$. The DNA bands were visualized under UV illumination.

\section{Annexin V/PI double staining assay for apoptosis}

Induction of apoptosis was determined by Annexin VFITC apoptosis detection kit (BD Hoffmann-La Roche Inc.) according to the manufacturer's instructions. Briefly, human colorectal (SW1116 and SW837) and breast (HTB26 and HTB132) cancer cell lines were plated $\left(5 \times 10^{5}\right.$ cells $\left./ \mathrm{ml}\right)$ in 24-well plate and incubated at $37^{\circ} \mathrm{C}$ in a non- $\mathrm{CO}_{2}$ incubator for $18 \mathrm{~h}$. The cells were treated with Nar $(3 \mathrm{mM})$ for $48 \mathrm{~h}$. Cells from control and treatment groups were re-suspended in $100 \mu \mathrm{l}$ of staining solution containing annexin $\mathrm{V}$ fluorescein and propidium iodide in HEPES buffer (Annex V-FITC, BD Pharmingen, San Diego, CA). Following incubation at room temperature for $15 \mathrm{~min}$, cells were analyzed by flow cytometry. Annexin V binds to those cells that express phosphatidylserine (PS) on the outer layer of the cell membrane, and propidium iodide stains the cellular DNA of those cells with a compromised cell membrane. This technique allows for the discrimination of live cells (unstained with either fluorochrome) from apoptotic cells (stained only with annexin V) and necrotic cells (stained with both annexin $\mathrm{V}$ and propidium iodide).

\section{Western blot analysis}

Expression of PI3K, phospho-Akt1/2/3 (Ser473), Akt, NFкBp65, pIкB $\alpha$ and $\beta$-actin at the level of translation was determined by western blot analysis as recently described [15] with some modifications. Human colorectal (SW1116) and breast (HTB26) cancer cell lines were plated $\left(5 \times 10^{5}\right.$ cells $\left./ \mathrm{ml}\right)$ in 24-well plates and incubated at $37^{\circ} \mathrm{C}$ in a non- $\mathrm{CO}_{2}$ incubator for 18 . The cells were treated with Nar $(3 \mathrm{mM})$ for $24 \mathrm{~h}$. Untreated and Nartreated cancer cells were scraped from the wells and collected by centrifugation $\left(1000 \times \mathrm{g}, 5 \mathrm{~min}, 4^{\circ} \mathrm{C}\right)$. The cells were then washed with ice-cold phosphate-buffered saline (PBS) and re-centrifuged. Nuclear fraction (NFkB) was prepared using cytosol/nuclear fractionation kit (BioVision, Inc.) according to the manufacturer instructions. Whole cell extract (PI3K, phospho-Akt, Akt, $\mathrm{pI} \mathrm{I} B \alpha$ and $\beta$-actin) was prepared as recently described (15). Briefly, the cell pellets obtained were re-suspended and lysed in buffer containing $20 \mathrm{mM}$ Tris (pH 7.4), $200 \mathrm{mM}$ sodium chloride, $1 \mathrm{mM}$ ethylenediaminetetraacetic acid (EDTA), $10 \mathrm{mM} \beta$-glycerophosphate, $10 \mathrm{mM}$ sodium pyrophosphate, $0.5 \%$ NP-40, $0.05 \%$ sodium deoxycholic acid, and protease inhibitor cocktail, and the lysates were clarified by centrifugation at $17000 \times \mathrm{g}$ for $30 \mathrm{~min}$ at $4^{\circ} \mathrm{C}$. Protein concentrations of nuclear fractions and whole cell extracts were measured using the Bradford assay (Bio-Rad, Hercules, CA). Untreated and Nartreated nuclear or whole cell extracts were mixed with equal volumes of $5 \times$ SDS sample buffer, boiled for $5 \mathrm{~min}$, and separated by $10-12 \%$ sodium dodecyl sulfatepolyacrylamide gel electrophoresis (SDS-PAGE). After electrophoresis, proteins were transferred to polyvinylidene difluoride (PVDF) membranes (Millipore, Billerica, MA). The membranes were blocked in 5\% nonfat dry milk dissolved in PBST $\left(3.2 \mathrm{mM} \mathrm{Na}_{2} \mathrm{HPO}_{4}, 0.5 \mathrm{mM} \mathrm{KH}_{2} \mathrm{PO}_{4}\right.$, $1.3 \mathrm{mM} \mathrm{KCl}, 135 \mathrm{mM} \mathrm{NaCl}, 0.05 \%$ Tween-20) overnight at $4^{\circ} \mathrm{C}$. Primary antibodies specific to PI3K, phosph-Akt1/ $2 / 3$ (Ser473), Akt, $\mathrm{pI} \kappa \mathrm{B} \alpha$ and $\beta$-actin (Santa Cruz, CA) were adsorbed to the membranes of whole cell extracts and primary antibody specific to NFkBp65 was adsorbed to the membrane of nuclear fractions. After washing with PBS containing $0.1 \%$ Tween 20, the blots were incubated with an alkaline phosphatase-conjugated species-specific IgG secondary antibody for $2 \mathrm{~h}$ at room temperature. Bound antibodies were detected using nitroblue tetrazolium and bromochloroindoyl-phosphate. The specificities of the antibodies used in this study were examined by testing their reactivity with unrelated antigens, such as bovine serum albumin (BSA). The signal intensities of the respective bands were quantified by GS-800 calibrated imaging densitometer (Bio-Rad Laboratories, Inc. CA, USA).

\section{Relative quantitative Real-Time PCR assay}

mRNA expression of cell cycle- and apoptosis-associated genes in control and Nar-treated cells was determined by real-time polymerase chain reaction (qRT-PCR) using an ABI 7000 SDS system (Applied Biosystems, USA) and the comparative $\Delta \Delta \mathrm{Ct}$ method [15]. Commercial assays that target specific genes with probes and primers were obtained from Applied Biosystems. The targets and their Applied Biosystems assay numbers for the cell- 
cycle regulatory genes were as follows: $c d k 4$ (assay ID: Hs00364847_m1); cdk6 (assay ID: Hs00608037_m1.); Cdk7 (assay ID: Hs00361486_m1); p18 (assay ID: Hs00176227_m1); $p 19$ (assay ID: Hs00176481_m1); and p21 (assay ID: Hs00355782_m1). The targets and their Applied Biosystems assay numbers for the pro-apoptotic, anti-apoptotic and caspase genes were as follows: Bax (assay ID: Hs00180269_m1); Bak (assay ID: Hs00832876_m1); AIF (assay ID: Hs00269879-m1); c-IAP-2 (assay ID: Hs00985029_m1); Bcl2 (assay ID: Hs00608023_m1); x-IAP (Assay ID: Hs00236913_m1); casp3 (assay ID: Hs00234387_m1); casp7 (assay ID: Hs00169152_m1); casp8 (assay ID: Hs01018151-m1); and casp9 (assay ID: Hs00154260_m1). GAPDH (assay ID: Hs99999905_m1) was used as an endogenous control to normalize the expression values for each sample. For the comparative Ct method, we performed a two-step RT-PCR to obtain cDNA and real-time quantification using the target gene expression assays and Taqman Universal Master Mix (Applied Biosystems). Colorectal and breast cancer cells $\left(5 \times 10^{5}\right.$ cells/ $\mathrm{ml}$ ) were plated in 24-well plates and incubated in a non- $\mathrm{CO}_{2}$ incubator for $18 \mathrm{~h}$. The cells were then treated with Nar $(3 \mathrm{mM})$ for $24 \mathrm{~h}$. mRNA was extracted using the nucleospin RNAII ready-to-use system (MACHEREY-NAGEL), and $200 \mathrm{ng} / \mu \mathrm{l}$ of mRNA was used in the RT reaction. Contaminated DNA was eliminated with DNase-I treatment for $20 \mathrm{~min}$ at $25^{\circ} \mathrm{C}$, followed by heat inactivation for $10 \mathrm{~min}$ at $65^{\circ} \mathrm{C}$, prior to cDNA synthesis using the high-capacity cDNA reverse transcription kit (Applied Biosystems) according to the manufacturer's instructions. For each sample, $2.5 \mu \mathrm{l}$ of cDNA and $12.5 \mu \mathrm{l}$ of Taqman Universal Master Mix $(2 \times)$ were used, and the final volume was adjusted to $25 \mu \mathrm{l}$ with nuclease-free water on an optical 96-well reaction plate (Applied Biosystems). Real-time PCR was performed on an ABI 7000 SDS system using ABI Prism's SDS collection software version 1.1 (Applied Biosystems). Real-time PCR conditions followed the protocol given by the manufacturer of the Taqman Universal Master Mix: step 1, $95^{\circ} \mathrm{C}$ for $10 \mathrm{~min}$; step 2, $94^{\circ} \mathrm{C}$ for $15 \mathrm{~s}$; and step $3,60^{\circ} \mathrm{C}$ for $1 \mathrm{~min}$. The samples were analyzed using SDS collection software version 1.1, with the baseline set between 3 and 15 and the threshold set at 0.2. The amount of target normalized to an endogenous reference and relative to a calibrator (untreated) was determined by $2^{-\Delta \Delta \mathrm{Ct}}$, and the $\log$ comparative $\mathrm{Ct}$ is presented graphically.

\section{Nar enhances the anticancer effects of DNA-acting drugs on colorectal and breast cancer cells}

The potential of Nar to sensitize human colorectal (SW1116, SW837) and breast (HTB26, HTB132) cancer cells to DNA-acting drugs was studied as previously described [17]. Briefly, cancer cells were plated $\left(27 \times 10^{3}\right.$ cells/well) in 96 -well plates at $37^{\circ} \mathrm{C}$ in a non- $\mathrm{CO}_{2}$ incubator. Eighteen hours after culture initiation, the cells were simultaneously treated for $24 \mathrm{~h}$ with $\mathrm{Nar}(1.0 \mathrm{mM})$ and various concentrations of the following DNA-damaging drugs: camptothecin (CPT), 5-fluorouracil (5FU), doxorubicin (DOX), cis-platin (CIP), ellipticine (ELP), and etoposide (ETP) at concentrations of $1 \times 10^{-10}-1 \times 10^{-3}$ $\mathrm{M}$; carboplatin (CAP) at concentrations of $1 \times 10^{-10}$ $1 \times 10^{-4} \mathrm{M}$; and cyclophosphamide (CPA) at concentrations of $1 \times 10^{-11}-1 \times 10^{-5} \mathrm{M}$. The drugs were then removed, the cells were washed with HBSS, and cell growth was monitored using an MTT assay.

\section{Statistical analyses}

The results are expressed as the mean \pm SEM of at least three independent experiments. Statistical analyses were performed with SPSS-21. The statistical significance of the differences between the control and treated groups were determined by one-way ANOVA. $P$ values $<0.05$ were considered significant.

\section{Results}

\section{Isolation and identification of $\mathrm{Nar}$}

Nar was isolated as yellow needles (EtOAc-ether): $m p$ 240-242 ${ }^{\circ}$; $\mathrm{UV}(\mathrm{MeOH}) \lambda_{\max }(\log \varepsilon) 240$ (3.75) nm; IR (KBr) $v_{\max } 3343,1639,1562,1515,1419 \mathrm{~cm}^{-1} ;{ }^{1} \mathrm{H}$ NMR $\left(\mathrm{CD}_{3} \mathrm{OD}, 600 \mathrm{MHz}\right)$ see Table $1 ;{ }^{13} \mathrm{C}$ NMR $\left(\mathrm{CD}_{3} \mathrm{OD}\right.$, $150 \mathrm{MHz})$ see Table 1; EIMS (70 eV) $m / z 272[\mathrm{M}]^{+}$.

\section{Anti-proliferative effects of Nar on human colorectal and breast cancer cells}

To investigate the effect of Nar on human colorectal and breast cancer cells, cell viability was studied using an MTT assay. Treatment of human colorectal (SW1116, SW837) and breast (HTB26, HTB132) cancer cell lines with various concentrations of $\mathrm{Nar}(0.5-4 \mathrm{mM})$ for $6-$ $24 \mathrm{~h}$ showed time- and dose-dependent anti-proliferative effects (Figure 1A, B). Treatment of SW1116 with Nar for 6 and $12 \mathrm{~h}$ produced $42 \pm 2.8 \%$ (Figure $1 \mathrm{Aa}$ ) and $52 \pm 3.5 \%\left(\mathrm{IC}_{50}=4 \mathrm{mM}\right)$ (Figure $\left.1 \mathrm{Ab}\right)$ growth inhibition, respectively. Nar did not show any effect on normal human fibroblast cells (CRL1554) at 6 and $12 \mathrm{~h}$, and the difference between the effects of Nar on SW1116 and CRL1554 was significant at $6 \mathrm{~h}(P \leq 0.008)$ and nonsignificant at $12 \mathrm{~h}(P \leq 0.093)$. In addition, treatment of SW1116 cells with Nar for $15 \mathrm{~h}$ markedly inhibited their growth $\left(\%\right.$ cytotoxicity $=0.0-98 \%, P \leq 0.004, \quad \mathrm{IC}_{50}=$ $1.73 \mathrm{mM}$ ) compared with its effect on CRL1554 cells (\% cytotoxicity $=0.0-34 \%$ ) (Figure 1Ac). Moreover, exposure of SW1116 cells to Nar for 18 h showed significantly greater $\left(\%\right.$ cytotoxicity $=0.0-99.4 \%, P \leq 0.007, \mathrm{IC}_{50}=$ $0.91 \mathrm{mM})$ growth inhibition than that exerted on CRL1554 cells (\% cytotoxicity $=0.0-26 \%$ ) (Figure 1Ad). 
Table 1 NMR Data of Nar ${ }^{\mathrm{a}}$

\begin{tabular}{|c|c|c|}
\hline Position & $\delta_{\mathrm{H}}(\mathrm{m}, J \mathrm{~Hz})$ & $\delta_{\mathrm{C}}, \mathrm{m}^{b}$ \\
\hline 2 & $5.33(\mathrm{dd}, 13.2,3.0)$ & $80.5, d$ \\
\hline \multirow[t]{2}{*}{3} & $3_{\mathrm{ax}} 3.11(\mathrm{dd}, 13.2,17.1)$ & $44.0, \mathrm{t}$ \\
\hline & $3_{\text {eq }} 2.69(d d, 17.1,3.0)$ & \\
\hline 4 & - & $197.8, \mathrm{~s}$ \\
\hline 5 & - & $165.5, \mathrm{~s}$ \\
\hline 6 & $5.90(d, 1.8)$ & $96.2, d$ \\
\hline 7 & - & $168.4, \mathrm{~s}$ \\
\hline 8 & $5.89(\mathrm{~d}, 1.8)$ & $97.1, d$ \\
\hline 9 & - & $164.9, \mathrm{~s}$ \\
\hline 10 & - & $103.4, \mathrm{~s}$ \\
\hline $1^{\prime}$ & - & $131.1, \mathrm{~s}$ \\
\hline $2^{\prime}$ & $7.32(\mathrm{dd}, 7.2,1.8)$ & $129.1, d$ \\
\hline $3^{\prime}$ & $6.83(\mathrm{dd}, 6.6,2.4)$ & $116.3, d$ \\
\hline $4^{\prime}$ & - & $159.0, \mathrm{~s}$ \\
\hline $5^{\prime}$ & $6.83(\mathrm{dd}, 7.2,1.8)$ & $116.3, d$ \\
\hline $6^{\prime}$ & $7.32(\mathrm{dd}, 7.2,1.8)$ & $129.1, d$ \\
\hline $\mathrm{OH}$ & $4.89(\mathrm{~s})$ & - \\
\hline
\end{tabular}

Furthermore, treatment of SW1116 cells with Nar for $24 \mathrm{~h}$ produced a higher growth inhibition (\% cytotoxicity $\left.=0.0-100 \%, \mathrm{IC}_{50}=1.0 \mathrm{mM}\right)$ than that produced on CRL1554 cells $(0.0-32 \%)$. The difference in the growth inhibition was significant $(P \leq 0.015)$ (Figure 1Ae).

Treatment of SW837 with various concentrations of Nar for $12 \mathrm{~h}$ produced a higher growth inhibition (\% cytotoxicity $=0.0-55 \%, P \leq 0.06, \mathrm{IC}_{50}=4.0 \mathrm{mM}$ ) than that produced on CRL1554 cells (\% cytotoxicity $=0-19 \%$ ) (Figure 1Ab). In addition, treatment of SW837 cells with Nar for $15 \mathrm{~h}$ produced a higher cytotoxicity (\% cytotoxicity $\left.=0.0-99.5 \%, P \leq 0.015, \mathrm{IC}_{50}=2.0 \mathrm{mM}\right)$ than that exerted on CRL1554 cells (\% cytotoxicity $=0-34 \%$ ) (Figure 1Ac). Moreover, exposure of SW837 cells to Nar for 18 h markedly inhibited their proliferation (\% cytotoxicity $=0.0-99.9 \%, P \leq 0.042, \mathrm{IC}_{50}=1.36 \mathrm{mM}$ ) compared with its effect on CRL1554 cells (\% cytotoxicity $=0.0-26 \%$ ) (Figure 1Ad). Further incubation of SW837 cells with Nar for $24 \mathrm{~h}$ produced a higher growth inhibition (\% cytotoxicity $=0.0-100 \%, P \leq 0.066, \mathrm{IC}_{50}=$ $1.55 \mathrm{mM}$ ) than that produced on CRL1554 cells (\% cytotoxicity $=0.0-32 \%$ ) (Figure 1Ae).

Treatment of the human breast cancer cell line HTB26 with Nar (0.2-4 mM) for $6 \mathrm{~h}$ exhibited a slight growth inhibition (\% cytotoxicity $=0-13 \%, P \leq 0.897$ ) with no effect on CRL1554 cells (Figure 1Ba). A higher growth inhibitory effect was observed on HTB132 cells (\% cytotoxicity $=0.0-52 \%, P \leq 0.035, \mathrm{IC}_{50}=4.0 \mathrm{mM}$ ) (Figure 1Ba.) after exposure to Nar for $6 \mathrm{~h}$. Exposure of
HTB26 cells for $12 \mathrm{~h}$ produced a substantially higher growth inhibition (\% cytotoxicity $=0.0-73 \%, P \leq 0.041$, $\left.\mathrm{IC}_{50}=3.09 \mathrm{mM}\right)$ compared with CRL1554 cells (\% cytotoxicity $=0.0-19 \%)$. A similar growth inhibition was noted with HTB132 cells treated with Nar for $12 \mathrm{~h}$ (\% cytotoxicity $=0.0-55 \%, P \leq 0.038 ; \mathrm{IC}_{50}=3.73 \mathrm{mM}$ ) (Figure 1Bb). Moreover, exposure of HTB26 to Nar for $15 \mathrm{~h}$ markedly inhibited its growth (\% cytotoxicity = $\left.0.0-100 \%, \mathrm{P} \leq 0.001, \mathrm{IC}_{50}=1.36 \mathrm{mM}\right)$ compared with CRL1554 cells (\% cytotoxicity $=0.0-34 \%$ ). Exposure of HTB132 cells to Nar for $15 \mathrm{~h}$ produced a higher antiproliferative effect (\% cytotoxicity $=0.0-67 \%, P \leq 0.007$, $\mathrm{IC}_{50}=3.0 \mathrm{mM}$ ) than that produced on CRL1554 cells (Figure 1Bc). In addition, exposure of HTB26 (\% cytotoxicity $\left.=0.0-99.6 \%, P \leq 0.011, \mathrm{IC}_{50}=1.46 \mathrm{mM}\right)$ and HTB132 (\% cytotoxicity $=0.0-95 \%, P \leq 0.005, \mathrm{IC}_{50}=$ $0.91 \mathrm{mM}$ ) cells to Nar for $18 \mathrm{~h}$ produced greater growth inhibition than that observed in CRL1554 cells (\% cytotoxicity $=0.0-26 \%$ ) (Figure 1Bd). Furthermore, a similar significant growth inhibition was observed in HTB26 (\% cytotoxicity $\left.=0.0-99.9 \%, P \leq 0.024, \mathrm{IC}_{50}=0.82 \mathrm{mM}\right)$ and HTB132 (\% cytotoxicity $=0.0-95.3 \%, P \leq 0.002, \mathrm{IC}_{50}$ $=0.36$ ) cells compared with CRL1554 cells (\% cytotoxicity $0.0-32 \%$ ) after a 24-h exposure to Nar (Figure 1Be).

The anti-proliferative effects of Nar on human colorectal (SW1116, SW837) and breast (HTB26, HTB132) cancer cells were confirmed by the inhibition of colony formation. Treatment of SW1116 cells with Nar markedly inhibited colony formation (mean number of colonies = $17 \pm 2, P \leq 0.0001)$ compared with untreated SW1116 cells (mean number of colonies $=152 \pm 1.84$ ) (Figure 1Ca). Additionally, exposure of SW837 cells to Nar greatly inhibited colony formation (mean number of colonies = $9 \pm 0.9, P \leq 0.0001)$ compared with untreated SW837 cells (mean number of colonies $=98 \pm 2.6$ ) (Figure $1 \mathrm{Cb}$ ).

Exposure of HTB26 cells to Nar showed a marked inhibition of colony formation (mean number of colonies = $11 \pm 1.6, P \leq 0.0001)$ compared with untreated HTB26 cells (mean number of colonies $=177 \pm 3$ ) (Figure 1Cc). Similar marked inhibition of colony formation was observed with Nar-treated HTB132 cells (mean number of colonies $=22 \pm 1.8, \quad P \leq 0.0001)$ compared with untreated HTB132 cells (mean number of colonies = $176 \pm 3$ ) (Figure 1Cd).

\section{Nar arrests the growth of human colorectal and breast cancer cells}

To further demonstrate that the growth inhibition of human colorectal and breast cancer cells leads to alterations of the cell cycle distribution, cells were treated with Nar and stained with PI. The percentage of cells in each stage of the cell cycle was analyzed using flow cytometry. Treatment of the human colorectal cancer cell line SW1116 with Nar for 24 h resulted in accumulation 

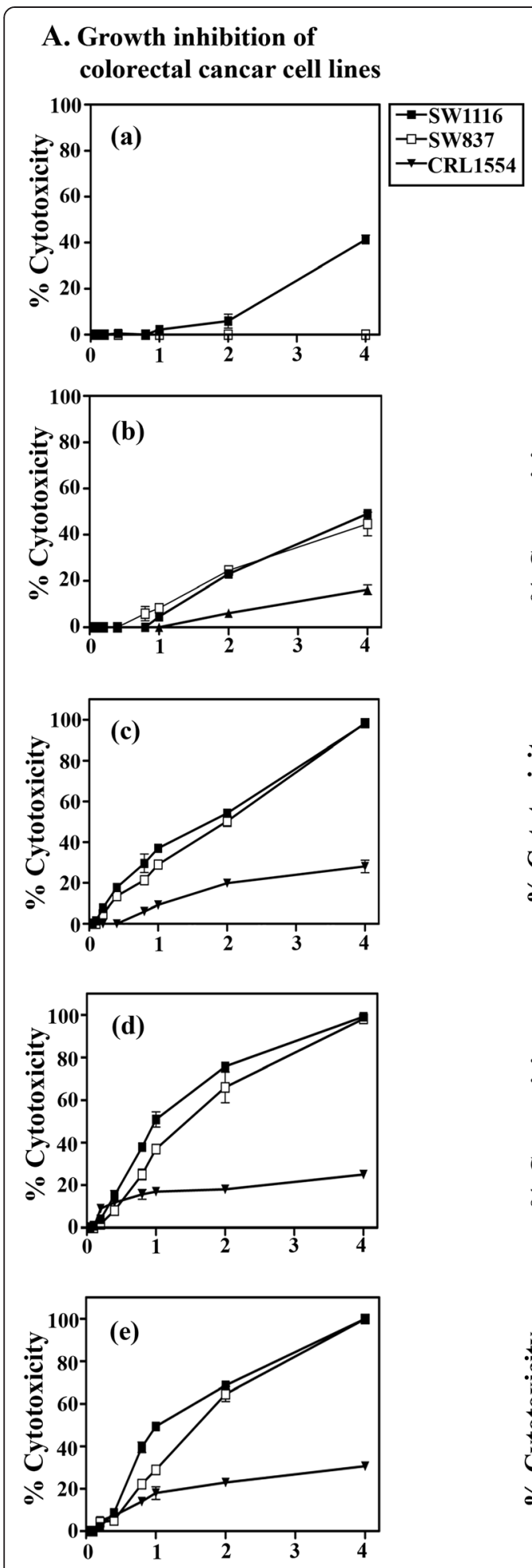

Conc. of Nar
B. Growth inhibition of breast cancer cell lines
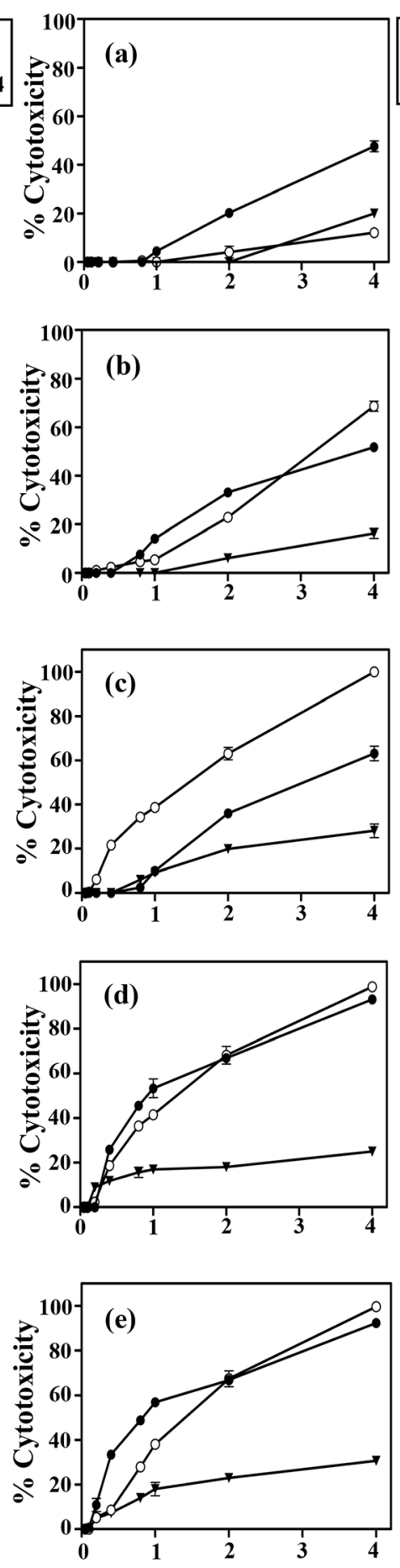

Conc. of Nar
C. Inhibition of colony formation
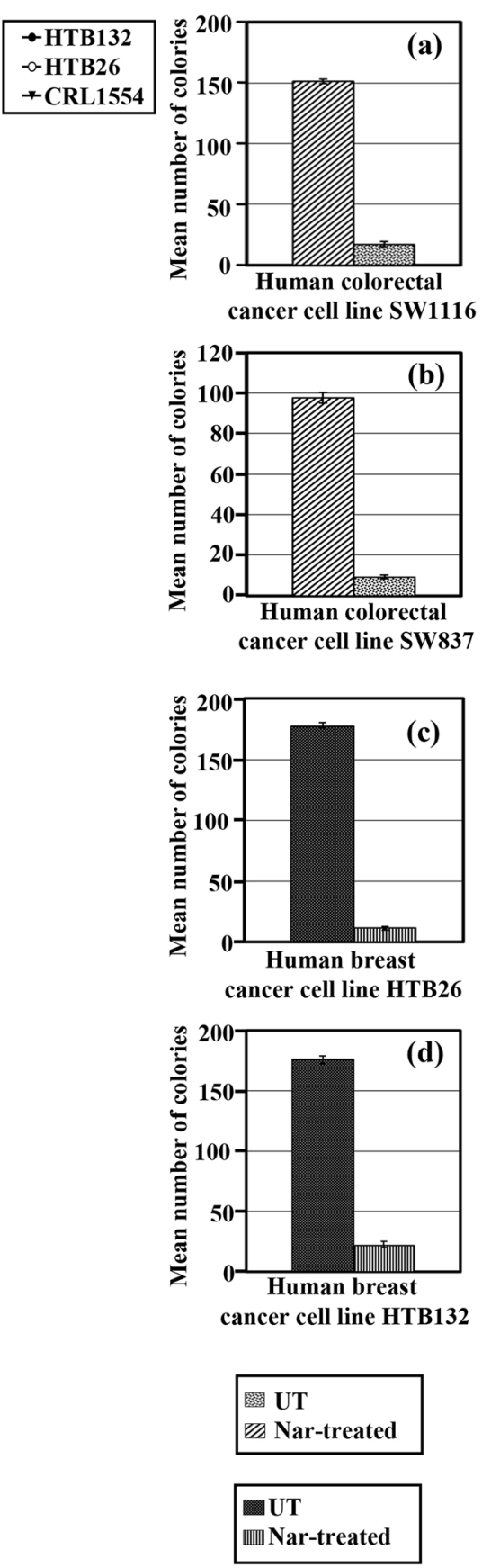

Figure 1 (See legend on next page.) 
(See figure on previous page.)

Figure 1 Time and dose-dependent anti-proliferative effects and inhibition of colony formation of Nar on human colorectal and breast cancer cell lines. Human colorectal cancer cells (SW1116, SW837) (A a-e), human breast cancer cells (HTB 26, HTB132) (B a-e) and normal human fibroblast cells (CRL1554) (A, B a-e) were plated $\left(27 \times 10^{3}\right.$ cells/well) in 96-well plates in $\mathrm{CO}_{2}$ and non- $\mathrm{CO}_{2}$ incubators, depending on type of media and cells, at $37^{\circ} \mathrm{C}$ for $18 \mathrm{~h}$. The cells were then treated with various concentrations of Nar (0.05 - 4.0 mM) for 3-24 h. Cell growth was monitored using an MTT assay. Untreated and Nar-treated colorectal cancer cells SW1116 (Ca), SW837 (Cb) and Nar-treated breast cancer cells HTB26 (Cc), HTB132 (Cd) were trypsinized, counted and plated (500 cells /well) in 6-well plates. Following 10-14 days of incubation in non- $\mathrm{CO}_{2}$ incubator at $37^{\circ} \mathrm{C}$, the colonies were fixed and stained with crystal violet. The stained colonies were counted and compared with the untreated control.

of cells in $\mathrm{S}$-phase $(53.8 \% \pm 2.2$ vs. $41.6 \% \pm 1.8$ for untreated; UT, $P \leq 0.005)$ and $\mathrm{G}_{2} / \mathrm{M}$-phase $(8.2 \% \pm 1.3 \mathrm{vs}$. $5.6 \% \pm 1.3$ for UT, $P \leq 0.204)$ with a corresponding decrease in the fraction of cells in $G_{0} / G_{1}$ phase $(37.8 \% \pm$ 1.7 vs. $52.76 \% \pm 1.2$ for UT, $P \leq 0.001$ ) (Figure $2 \mathrm{Aa}, \mathrm{b}$ ). Furthermore, Nar growth-arrested SW837 cells in both S-phase $(48 \% \pm 1.73$ vs. $43.4 \% \pm 1.96$ for UT, $P \leq 0.123)$ and $\mathrm{G}_{2} / \mathrm{M}$-phase $(14.7 \% \pm 1.2$ vs. $12.8 \% \pm 1.1$ for UT, $P \leq 0.471$ ) with a corresponding decrease of cells in
$\mathrm{G}_{0} / \mathrm{G}_{1}$-phase $(37.1 \% \pm 1.2$ vs. $43.7 \% \pm 2.7$ for UT, $P \leq$ 0.045) (Figure 2Ac, d).

On the other hand, treatment of the human breast cancer cell line HTB26 with Nar resulted in accumulation of HTB26 cells in both S-phase $(49 \% \pm 1.2$ vs. $47.1 \pm 1.2$ for UT, $P \leq 0.289)$ and $G_{2} / M$-phase $(13.7 \% \pm$ 1.2 vs. $7.5 \% \pm 1.4$ for UT, $P \leq 0.013$ ), with a corresponding decrease of cells in $G_{0} / G_{1}$-phase $(37.2 \% \pm 1.7$ vs. $45.3 \% \pm 1.9$ for UT, $P \leq 0.019$ ) (Figure $2 \mathrm{Ba}, \mathrm{b}$ ). Additionally,

\section{A. Cell cycle arrest of colorectal cancer cells - treated with Nar}

(a) Untreated SW1116

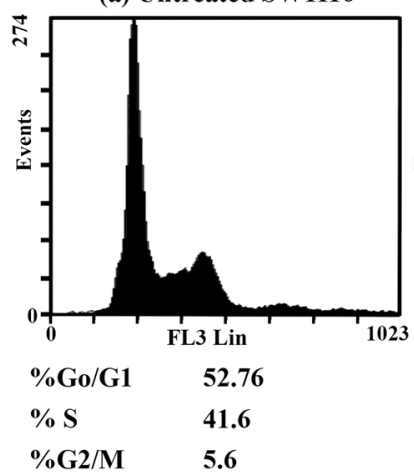

(b) Nar - Treated SW1116

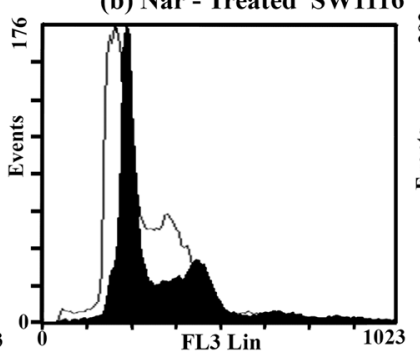

37.8

53.8

8.2 (c) Untreated SW837

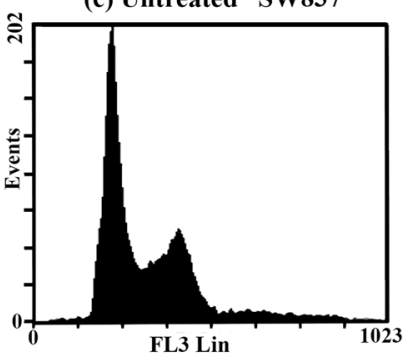

43.7

43.4

12.8 (d) Nar - Treated SW837

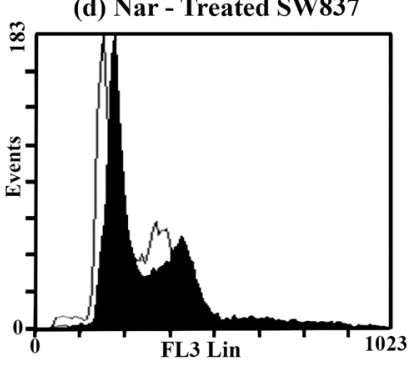

37.1

48

14.7

B. Cell cycle arrest of breast cancer cells - treated with Nar

(a) Untreated - HTB26
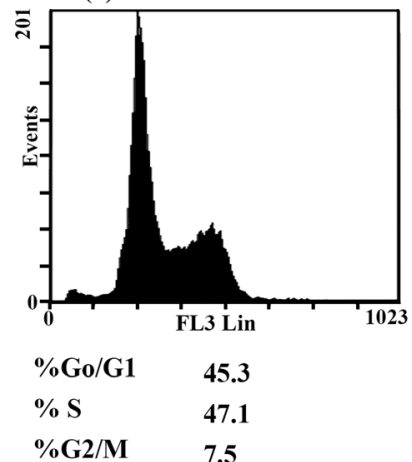

(b) Nar - treated - HTB26

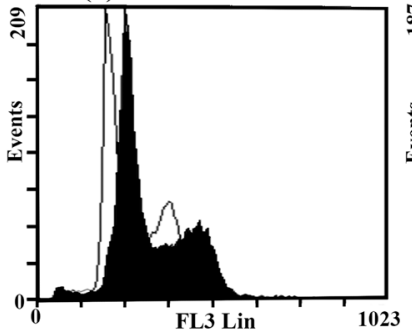

37.2

49

13.7 (c) Untreated - HTB132

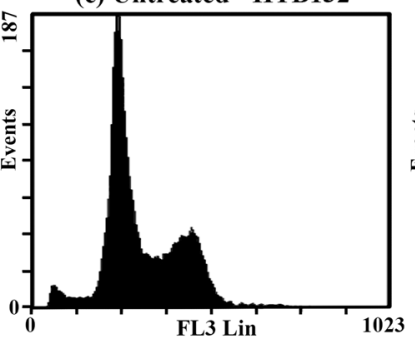

45.8

45.4

8.6 (d) Nar - treated HTB132

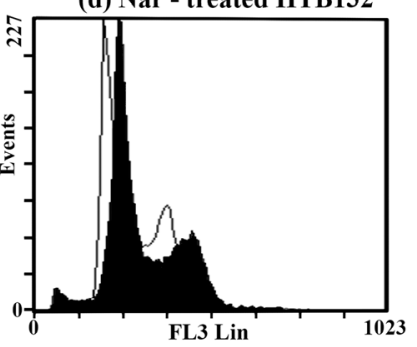

35.7

49.6

14.6

Figure 2 Analysis of cell cycle perturbation of human colorectal and breast cell lines treated with Nar. Human colorectal cancer cells (A) and human breast cancer cells $\mathbf{( B )}$ were plated $\left(2.5 \times 10^{5} \mathrm{cells} /\right.$ well) into 24 -well plates in a non-CO2 incubator at $37^{\circ} \mathrm{C}$ for $18 \mathrm{~h}$. The cells were then treated with $\operatorname{Nar}(3.0 \mathrm{mM}$ ) for $24 \mathrm{~h}$. At least three samples were analyzed, and 20,000 events were scored for each sample. The vertical axis represents the relative number of events, and the horizontal axis represents the fluorescence intensity. 
exposure of HTB132 cells to Nar resulted in accumulation of HTB132 cells in S-phase $(49.6 \% \pm 2.3$ vs. $45.4 \% \pm$ 2.3 for UT, $P \leq 0.246)$ and $\mathrm{G}_{2} / \mathrm{M}$-phase $(14.6 \% \pm 1.7$ vs. $8.6 \% \pm 1.2$ for UT, $P \leq 0.035)$ with a corresponding decrease of cells in $\mathrm{G}_{0} / \mathrm{G}_{1}$-phase $(35.7 \% \pm 2.3$ vs. $45.8 \% \pm 2.3$ for $\mathrm{UT}, P \leq 0.021$ ) (Figure 2Bc, $\mathrm{d}$ ).

\section{Nar induces apoptosis in human colorectal and breast cancer cells}

Agents with the ability to induce apoptosis in tumors have the potential to be used for antitumor therapy. The effect of Nar $(3 \mathrm{mM})$ on the induction of programmed cell death in human breast (HTB26 and HTB132) and colorectal (SW1116 and SW837) cancer cell lines was assessed with DNA fragmentation analysis. The results from DNA gel electrophoresis showed the formation of DNA laddering in both breast and colorectal cancer cell lines treated with Nar (data not shown).
To investigate the type of cell death induced by Nar, cells were stained with annexin V-FITC/PI and analyzed by flow cytometry. Annexin $\mathrm{V}$ is a $\mathrm{Ca}^{2+}$-dependent phospholipid-binding protein possessing a high affinity for PS, a membrane-bound component localized to the inner surface of the cell membrane. An indicator of early-stage apoptosis is the detection of exposed PS residues that have translocated to the cell surface. The annexin $\mathrm{V}$ assay permits the simultaneous detection of early apoptotic events based on annexin $\mathrm{V}$ binding to exposed PS and late apoptotic/dead events through the uptake of propidium iodide.

Treatment of SW1116 cells with Nar induced apoptosis, including early apoptosis ( $6.1 \%$ vs. $2.8 \%$ for UT), late apoptosis ( $56.4 \%$ vs. $2.5 \%$ for UT) and necrosis (29.9\% vs. $1 \%$ for UT) (Figure 3Aa, b). Similar results were obtained with SW837 cells treated with Nar, which showed early apoptosis ( $3.7 \%$ vs. $3.5 \%$ for UT), late

A. Induction of apoptosis in human colorectal cancer cells-treated with Nar.

(a) Untreated SW1116

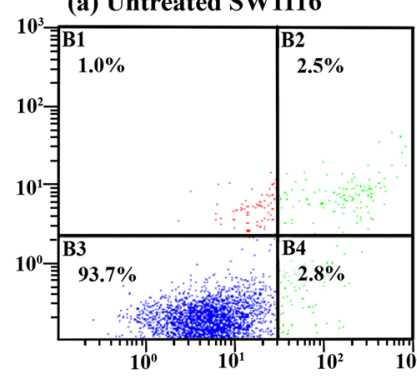

B3: \%Living cells

B4: \% Early apoptosis $\quad 2.8$

B2: \% Late apoptosis $\quad 2.5$

B1: \% Necrosis (b) Nar - treated SW1116

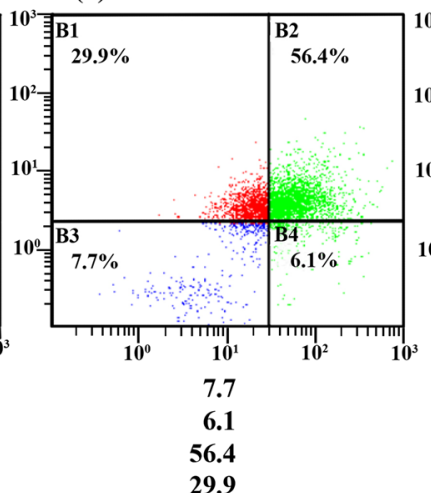

(c) Untreated SW837

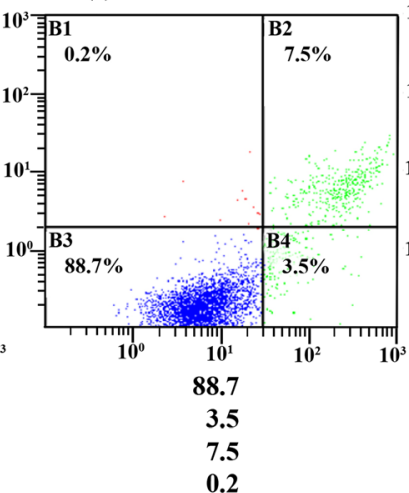

(d) Nar - treated SW837

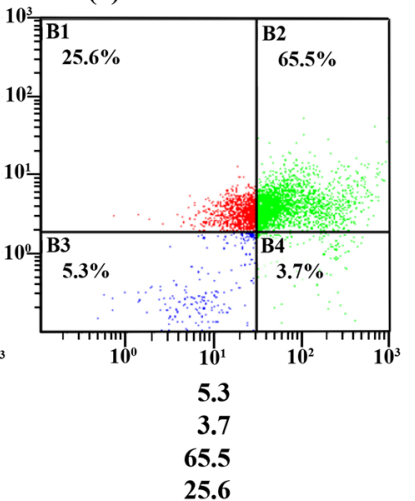

B. Induction of apoptosis in human breast cancer cells-treated with Nar.

(a) Untreated - HTB26

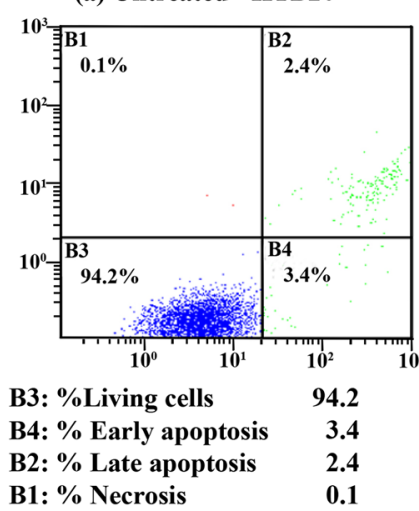

(b) Nar - HTB26

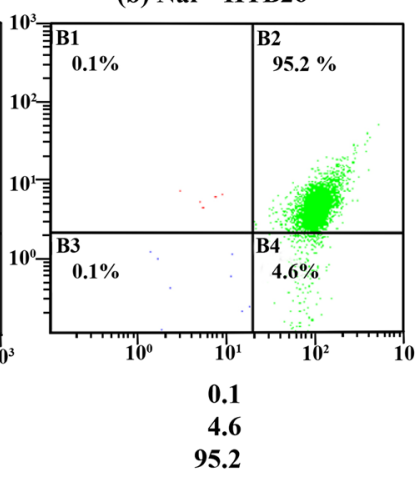

(c) Untreated SW837

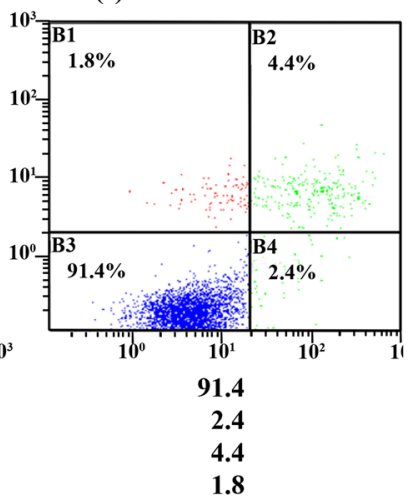

(d) Nar - treated HTB132

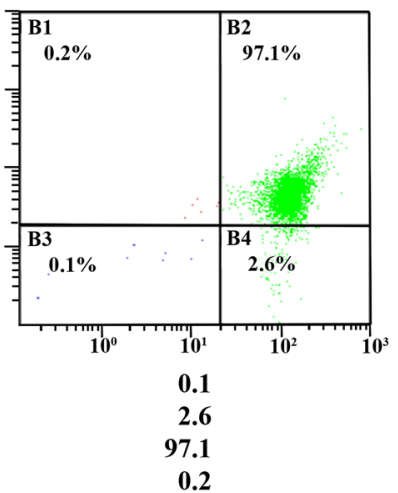

Figure $\mathbf{3}$ Induction of apoptosis in human colorectal and breast cancer cells treated with Nar. Human colorectal cancer cells (A) and human breast cancer cells $(\mathbf{B})$ were plated $\left(2.5 \times 10^{5}\right.$ cells/well) into 24 -well plates in non-CO2 incubator at $37^{\circ} \mathrm{C}$ for $18 \mathrm{~h}$. The cells were then treated with $\operatorname{Nar}(3.0 \mathrm{mM})$ for $48 \mathrm{~h}$. The cells were processed and stained with annexin V-FITC/PI and analyzed by flow cytometry as described in the Materials and Methods section. 
apoptosis (65.5\% vs. $7.5 \%$ for UT) and necrosis $(25.6 \%$ vs. $0.2 \%$ for UT) (Figure 3Ac, d). Moreover, exposure of the human breast cancer cell line HTB26 to Nar induced apoptosis, including early apoptosis (4.6\% vs. $3.4 \%$ for UT), late apoptosis ( $95.2 \%$ vs. $2.4 \%$ for UT) and necrosis $(0.1 \%$ vs. $0.1 \%$ for UT) (Figure $3 \mathrm{Ba}, \mathrm{b})$. Similar results were obtained with the breast cancer cell line HTB132, in which Nar induced apoptosis with early apoptosis ( $2.6 \%$ vs. $2.4 \%$ for UT), late apoptosis $(97.1 \%$ vs. $4.4 \%$ for UT) and necrosis $(0.2 \%$ vs. $1.2 \%$ for UT) (Figure 3Bc, d).

\section{Nar affects the expression of Akt, pAkt, PI3K, plkBa and NFKBp65 in colorectal and breast cancer cells}

Nuclear factor $-\kappa B($ NF- $\kappa B)$, a major cell survival signal, participates in multiple steps in cancer cell resistance to chemical and radiation therapies. Studies with animal models and cell culture systems have established links between NF- $\mathrm{kB}$ and carcinogenesis, highlighting its significance as a target in cancer treatment and chemoprevention [18]. We therefore tested the possibility that Nar might inhibit NF- $\mathrm{KB}$ in colorectal and breast cancer cells. Indeed, Nar inhibited the phosphorylation of $\mathrm{I} \mathrm{B}$, an upstream mediator of NF- $\mathrm{kB}$ function, and thus, p65 localization into nuclear was also inhibited in colorectal and breast cancer cells treated with Nar (Figure 4a, b), supporting the involvement of NF- $\mathrm{kB}$ inactivation in Nar-induced apoptosis. It is known that PI3K and its downstream substrate Akt also have a role in apoptosis [19]. We examined the expression of these proteins, identifying dose-dependent reductions in PI3K (Figure 4c), phospho-Akt (Figure 4d), Akt (Figure 4e) and the ratio of pAkt/Akt in both colorectal and breast cancer cell lines.

\section{Nar modulates the expression of genes-related to cell cycle} and apoptosis in human colorectal and breast cancer cells Inhibition of the cell cycle and the induction of apoptosis in cancer cells are two major goals in cancer treatment. Therefore, we analyzed the expression of genes controlling both cell cycle and apoptosis in human cancer cells treated with Nar to elucidate the potential molecular anticancer mechanisms of Nar, which remains unclear.

Cell cycle progression in eukaryotic cells is partly controlled by the cyclin-dependent kinase (Cdk) family of protein kinases, their activating partners, the cyclins, and the cyclin-dependent kinase inhibitors (CdkIs) [20].

Our data showed that Nar differentially downregulated the expression of $C d k 4, C d k 6$, and $C d k 7$ in the human colorectal cancer cell lines SW1116 (Figure 5Aa) and SW837 (Figure 5Ab) and in the human breast cancer cell lines HTB26 (Figure 5Ba) and HTB132 (Figure 5Bb). In contrast, Nar differentially upregulated the expression of $p 18, p 19$, and $p 21$ in both human colorectal cancer cell lines, SW11116 (Figure 5Ac) and SW837 (Figure 5Ad), and breast cancer cell lines, HTB26 (Figure $5 \mathrm{Bc}$ ) and HTB132 (Figure 5Bd).

On the basis of these observations, we propose that alterations in the level of various cell cycle regulatory proteins were responsible for the cell cycle arrest observed in Nar-induced death in human colorectal and breast cancer cells. Cell cycle arrest may, at least partially, account for the induction of apoptosis and the cytotoxic effects of Nar in human colorectal and breast cancer cells.

Pro-apoptotic and anti-apoptotic proteins are central regulators of apoptosis, and the interactions among these proteins set the threshold for cell survival [21]. Nar differentially up-regulated the expression of the pro-apoptotic genes, including caspases-3, 7, 8, 9, Bak, AIF and Bax in SW1116 (Figure 6Aa) and SW837 (Figure 6Ab) as well as HTB26 (Figure 6Ba) and HTB132 (Figure 6Bb). Meanwhile, Nar differentially downregulated anti-apoptotic genes, such as $B c l 2, x$ $I A P$ and $c-I A P-2$, in both SW1116 (Figure 6Ac) and SW837 (Figure 6Ad), as well as HTB26 (Figure 6Bc) and HTB132 (Figure 6Bd). Nar promotes apoptosis in human colorectal and breast cancer cells by altering the ratio of pro and anti-apoptotic genes in favor of apoptosis.

\section{Nar enhances the sensitivity of colorectal and breast cancer cells to DNA-acting drugs}

The potential of Nar to potentiate the chemo-sensitivity of colorectal and breast cancer cells to DNA-damaging drugs was examined. The results are summarized in Figures 7 and 8 and Table 2. The results reported in this study clearly indicate the potential of Nar to increase the sensitivity of colorectal and breast cancer cells to DNAdamaging drugs. The synergistic and/or additive interaction between the tested DNA-acting drugs and Nar needs to be further investigated and might be dependent on the type of drug tested, the polymorphism of the genes encoding the drug-metabolizing enzymes transporters or drug targets.

\section{Discussion}

The need for new drugs has prompted studies evaluating possible anticancer agents in fruits, vegetables, herbs, and spices. Natural products with diverse bioactivities are becoming an important source of novel agents with pharmaceutical potential. The potential for plant extracts to act as anticancer therapeutic agents is due to their ability to inhibit tumor growth, angiogenesis, and metastasis with few side effects [22]. Much of this activity appears to stem from flavonoids, which are principal components of many such extracts that demonstrate the capacity to inactivate carcinogens, inhibit angiogenesis, 


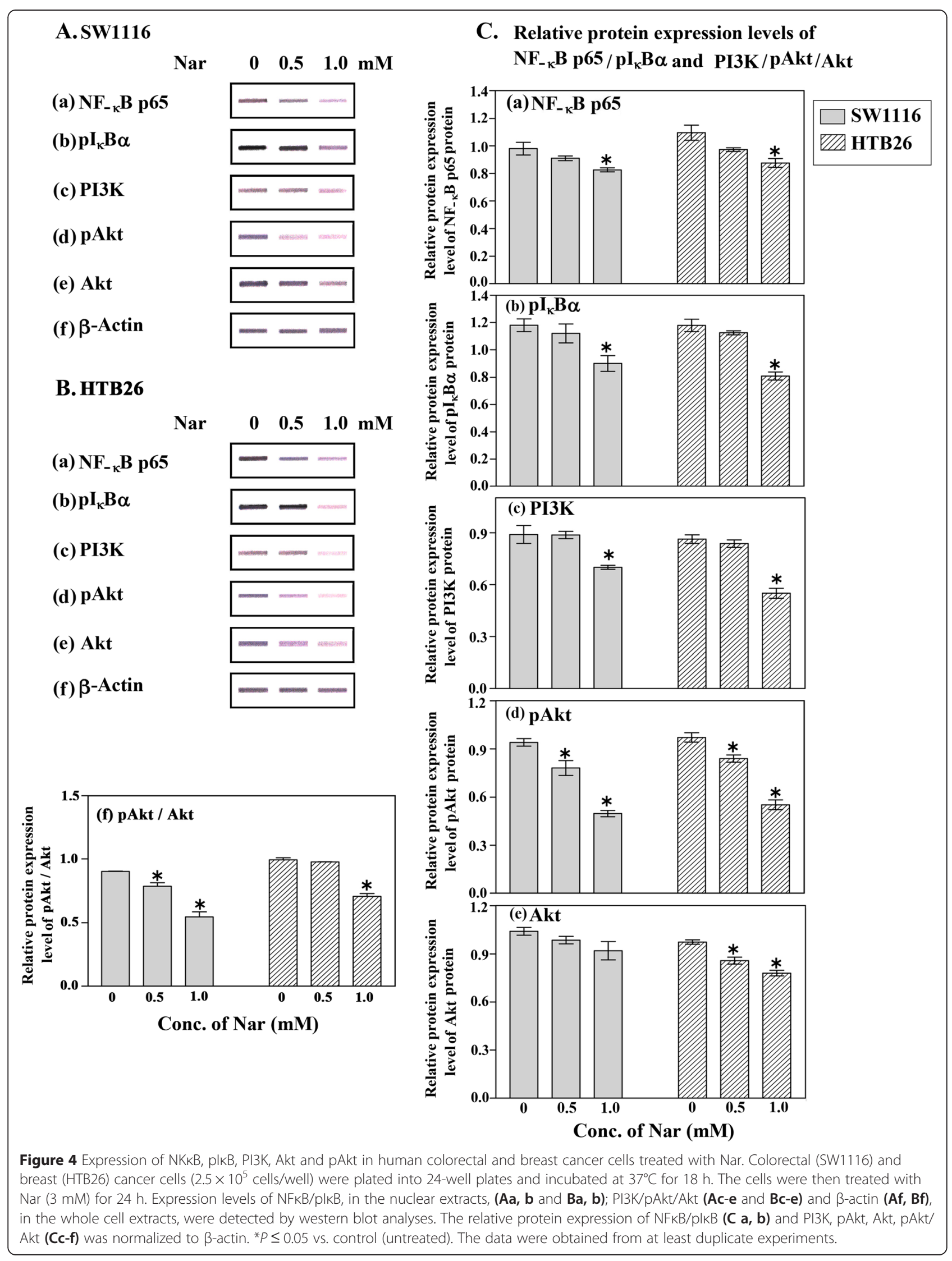


A. mRNA expression of CDKs and CDKIs in human colorectal cancer cell lines-treated with Nar.

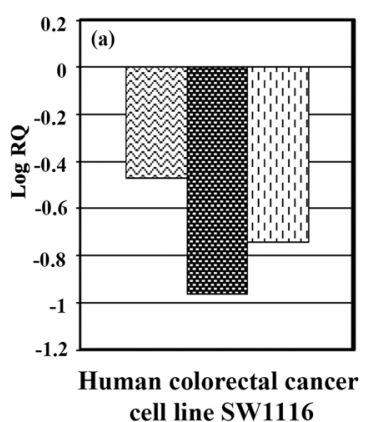

cell line SW1116

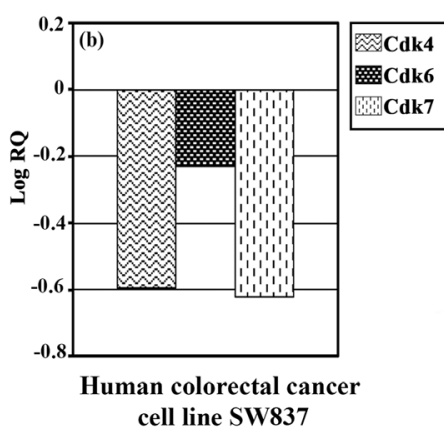

cell line SW837

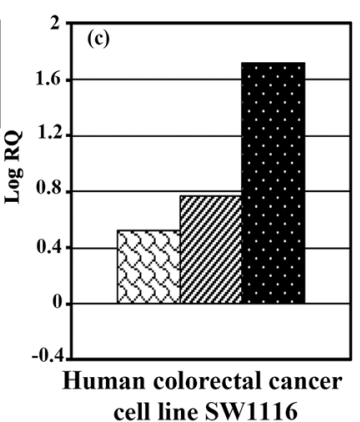

cell line SW1116

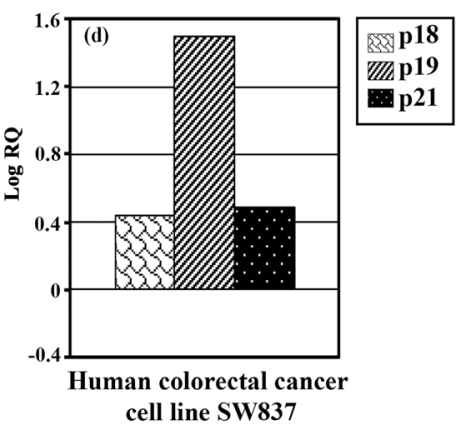

B. mRNA expression of CDKs and CDKIs in human breast cancer cell lines-treated with Nar.

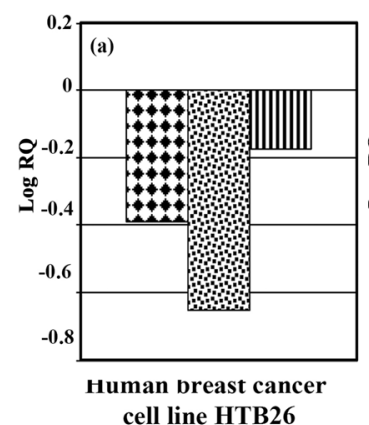

cell line HTB26
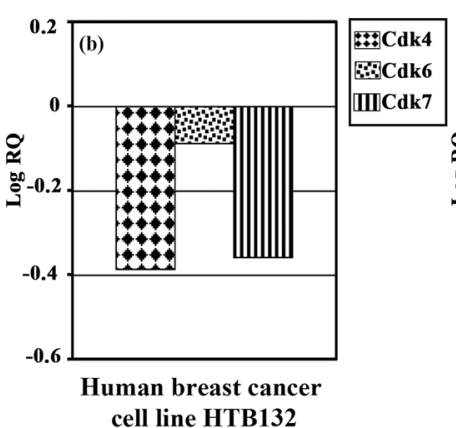

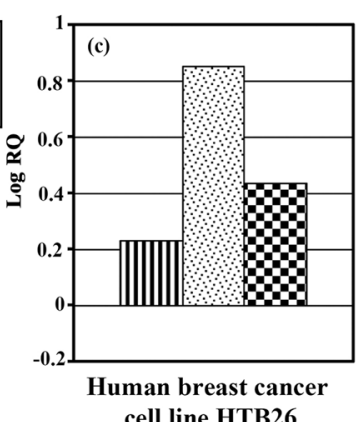

cell line HTB26

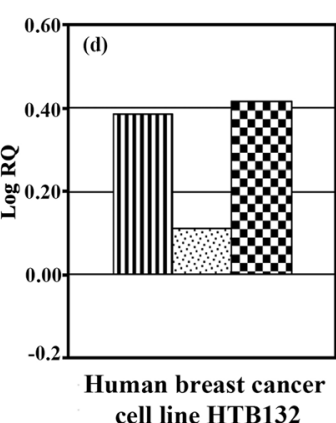

cell line HTB132

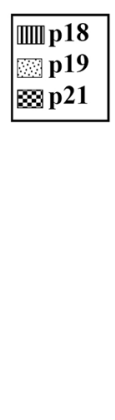

Figure 5 mRNA expression of cyclin-dependent kinase and cyclin-dependent kinase inhibitor genes in human colorectal and breast cancer cells treated with Nar. The expression of cyclin-dependent kinase genes and cyclin-dependent kinase inhibitor genes in human colorectal (A) and breast cancer cell lines (B) was determined by measuring mRNA levels through real-time RT-PCR and using the comparative $\Delta \Delta C t$ method to calculate expression changes. The amount of the target, normalized to an endogenous reference and relative to calibrator, is given by $2^{-\Delta \Delta C t}$.

and halt cell proliferation or promote apoptosis [23]. Nar, the aglycone of naringin, is a flavonoid with activity against uterine, blood, stomach, brain, and lung cancer cell lines [24] with no toxic effect on normal cells [25,26]. Its inhibitory effects on tumor growth have spurred interest in its therapeutic application. However, the detailed molecular mechanisms of its anti-proliferative effects and apoptosis induction on human colorectal and breast cancer cells remained to be elucidated. In this study, we endeavored to investigate the effects of Nar on human colorectal and breast cancer cell growth, the intracellular transduction pathways that regulate apoptosis and the potential for Nar to enhance the sensitivity of both colorectal and breast cancer cells to DNA-acting drugs.

The dried powdered Thymus vulgaris was percolated repeatedly in $96 \% \mathrm{EtOH}$ at room temperature. The combined extracts were evaporated in vacuo until desiccation. A total of $10 \mathrm{~g}$ of the dried residue was partitioned successively, between water and ethyl acetate. Flash chromatography of the ethyl acetate fraction over silica gel, using $15 \%$ acetone in chloroform as an eluent, yielded the known flavanone Nar [27] in addition to the flavanonol aromadendrin [28], and Nar was isolated as pale yellow needles. Its molecular formula was determined as $\mathrm{C}_{15} \mathrm{H}_{12} \mathrm{O}_{5}$ on the basis of the ion peak at $\mathrm{m} / \mathrm{z}$ $272[\mathrm{M}]^{+}$and NMR data. Its IR spectrum showed absorption bands for a hydroxyl group $\left(3343 \mathrm{~cm}^{-1}\right)$, a conjugated carbonyl group $\left(1639 \mathrm{~cm}^{-1}\right)$ and an aromatic moiety $\left(1562,1515\right.$, and $\left.1419 \mathrm{~cm}^{-1}\right)$. The ${ }^{1} \mathrm{H}$ and ${ }^{13} \mathrm{C}$ NMR spectra identified the possible identity of this compound as a flavanone. The ${ }^{13} \mathrm{C}$ NMR spectrum showed fifteen carbon resonances distributed as a triplet, five doublets (two of them are of double intensity) and seven singlets. The double intensity doublets resonated in the aromatic region (at $\delta_{\mathrm{C}} 116.3$ and 129.1, Table 1), indicating the presence of a para-di-substituted aromatic ring; two resonances of the remaining doublets resonated, again, in the aromatic region of $\delta_{\mathrm{C}} 96.2$ and 97.1 (Table 1).

The coupling pattern and constants in the ${ }^{1} \mathrm{H}$ NMR spectrum confirmed the presence of 1,2,3,5-tetrasubstituted and 1,4-disubstituted aromatic rings (ring $\mathrm{A}$ and ring $\mathrm{B}$, respectively). The last doublet resonated in the oxygenated aliphatic region at $\delta_{\mathrm{C}} 80.5 \mathrm{ppm}(\mathrm{C}-2)$, while the only triplet carbon resonated at $\delta_{\mathrm{C}} 44.0 \mathrm{ppm}(\mathrm{C}-3)$. This result confirmed the presence of a flavanone ring 


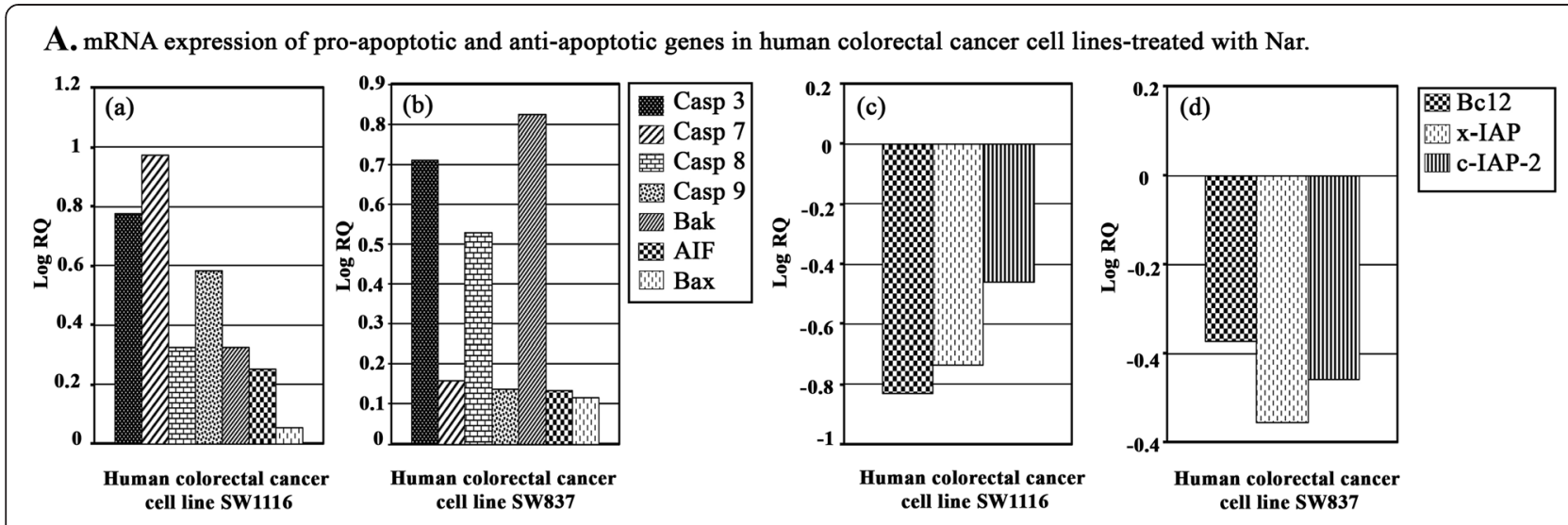

B. mRNA expression of pro-apoptotic and anti-apoptotic genes in human breast cancer cell lines-treateal with Nar.
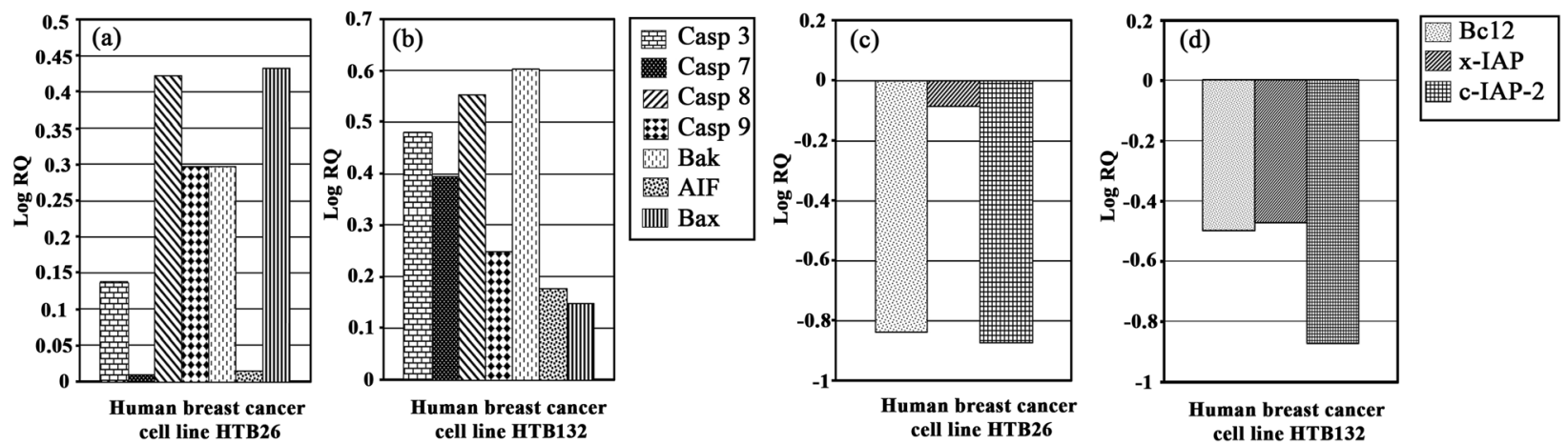

Figure 6 mRNA expression of pro-apoptotic and anti-apoptotic genes in human colorectal and breast cancer cells treated with Nar. The expression of pro-apoptotic and anti-apoptotic genes in human colorectal (A) and breast (B) cancer cells was determined by measuring mRNA levels through real-time RT-PCR and using the comparative $\Delta \Delta \mathrm{Ct}$ method to calculate expression changes. The amount of the target normalized to an endogenous reference and relative to calibrator, is given by $2^{-\Delta \Delta C t}$.

system. The HSQC spectra showed a cross peak between $\mathrm{C}-2\left(\delta_{\mathrm{C}} 80.5\right)$ and a proton resonated at $\delta_{\mathrm{H}} 5.33$ as a double doublet with $J=13.2,3.0 \mathrm{H}_{\mathrm{Z}}(\mathrm{H}-2)$. This coupling constant and pattern are only possible when $\mathrm{H}-2$ adapts an axial $(\beta-)$ orientation. Ring $B$, however, is attached to $\mathrm{C}$-2 with an $\alpha$-disposition. Therefore, the absolute stereochemistry around $\mathrm{C}-2$ was assigned as $S$. The $\mathrm{D}_{2} \mathrm{O}$-exchangeable sharp singlet resonating at $\delta_{\mathrm{H}}$ 4.89 indicated the presence of at least one hydroxyl group. Other HSQC, HMBC and COSY spectra facilitated the full unambiguous assignment of the protons and carbons of this compound and revealed its identity as the known flavanone Nar [27].

The anti-proliferative effects of Nar on colorectal (SW1116, SW837) and breast (HTB26, HTB132) cancer cells as well as normal human fibroblast CRL1554 cells were investigated first. Nar was found to be cytotoxic to both colorectal and breast cancer cells in a dose- and time-dependent manner. CRL1554 human fibroblast control cells were slightly affected by Nar. Therefore, Nar appeared to reduce cancer cell growth with minimal collateral damage. These results are in line with those reported in other studies using Nar or Nar derivatives in various cancer cell lines or animal models [29,30]. Our results contradict the recent findings that Nar exhibits no anti-cancer activity against human cervical cancer cells [31]. Very recently, the nano-chemoprevention concept was introduced as a novel approach for improving phytochemical bioavailability and anti-tumor effects. Oral administration of Nar-loaded nanoparticles (NARNPs) to 7,12-dimethylbenz(a)anthracene (DMBA)-treated animals completely prevented tumor formation compared with the free Nar and significantly reduced the degree of histological lesions, in addition to restoration of the status of biochemical and molecular markers during oral carcinogenesis [32]. NARNPs were found to have a more potent antitumor effect than free Nar in completely preventing the formation of squamous cell carcinoma and in restoring the biochemical constituents to normal range [33].

Cell cycle arrest and apoptosis are two important mechanisms involved in anti-cancer drug treatment [34]. Uncontrolled cellular proliferation is a hallmark of all 

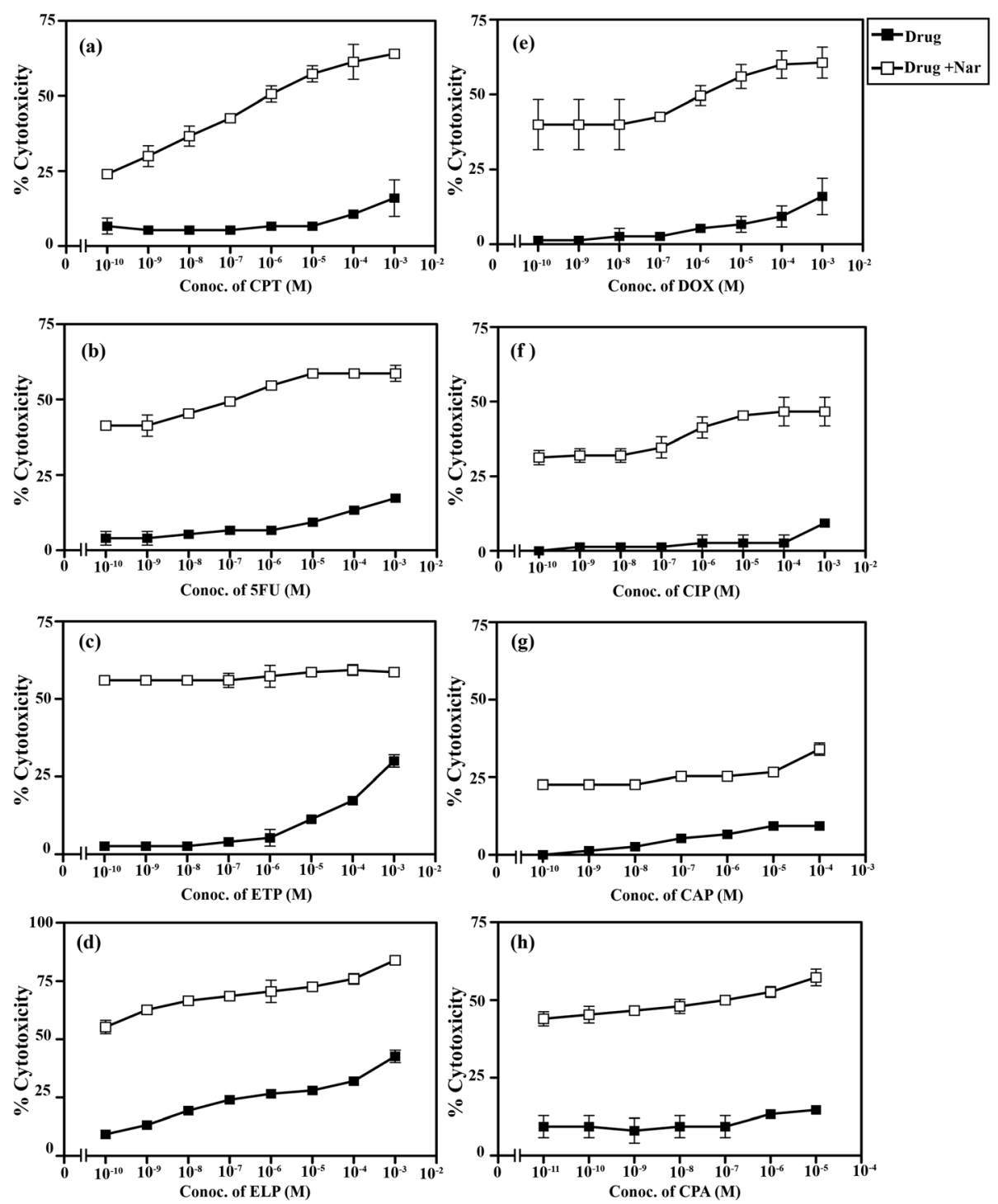

Figure 7 Nar enhances the chemosensitivity of human colorectal cancer cells to DNA-acting drugs. Human colorectal cancer cells SW1116 were plated $\left(27 \times 10^{3}\right.$ cells/well) into a 96-well plate at $37^{\circ} \mathrm{C}$ in a non- $\mathrm{CO}_{2}$ incubator. At $18 \mathrm{~h}$ after starting the culture, the cells were treated for $24 \mathrm{~h}$ with Nar $(1 \mathrm{mM})$ and various concentrations of camptothecin, CPT doxorubicin, DOX, 5-fluorouracil, 5FU cisplatin, CIP, etoposide, ETP ellipticine, ELP $\left(1 \times 10^{-10}-1 \times 10^{-3} \mathrm{M}\right)$, carboplatin, CAP $\left(1 \times 10^{-10}-3.5 \times 10^{-4} \mathrm{M}\right)$ and cyclophosphamide, CPA $\left(1 \times 10^{-11}-1 \times 10^{-5} \mathrm{M}\right)$. Cell proliferation was monitored using an MTT assay.

cancer, and the blockade of the cell cycle is regarded as an effective strategy for eliminating cancer cells [35]. Many chemotherapeutic agents have been shown to impart anti-proliferative effects via arresting cell division at certain checkpoints in the cell cycle [36]. The concept of cell cycle-mediated apoptosis has gained increasing attention, as targeting this pathway may provide an opportunity to overcome acquired drug resistance, decrease mutagenesis and reduce toxicity [36].

In the present study, cell cycle arrest was observed when cells were cultured with Nar. Characterization of this effect demonstrated that expression levels of cell cycle regulators were modulated by Nar treatment; arrest appeared to occur at S- and $\mathrm{G}_{2} / \mathrm{M}$-phases in both colorectal and breast cancer cells. These results are consistent with those reported in other studies using different types of malignancies [31].

Numerous studies have helped scientists appreciate apoptosis as an ideal way to eliminate precancerous and/ or cancer cells [37]. However, most cancer cells block apoptosis, which allows malignant cells to survive despite genetic and morphologic transformation. Therefore, searching for agents that can trigger apoptosis in tumor cells has become an attractive strategy in anti-cancer drugs discovery. Here, Nar markedly induced apoptosis in both colorectal and breast cancer cell lines. The 

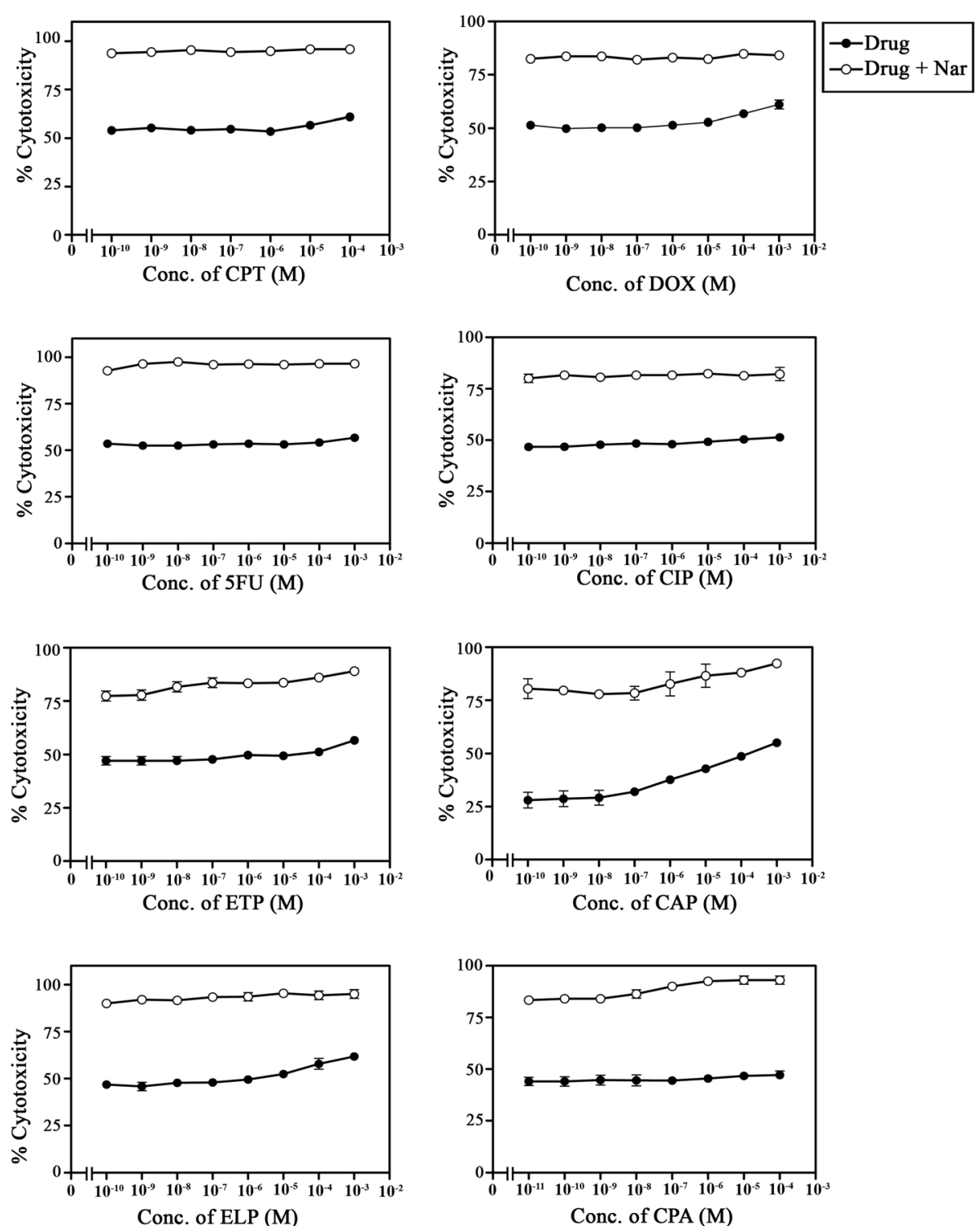

Figure $8 \mathrm{Nar}$ enhances the chemosensitivity of human breast cancer cells to DNA-acting drugs. Human breast cancer cells HTB26 were plated $\left(27 \times 10^{3}\right.$ cells/well) into a 96-well plate at $37^{\circ} \mathrm{C}$ in a non- $\mathrm{CO}_{2}$ incubator. At $18 \mathrm{~h}$ after starting the culture, the cells were treated for $24 \mathrm{~h}$ with $\mathrm{Nar}$ $(1 \mathrm{mM})$ and various concentrations of camptothecin, CPT, doxorubicin, DOX, 5-fluorouracil, 5FU, cisplatin, CIP, etoposide, ETP, ellipticine, ELP $(1 \times$ $\left.10^{-10}-1 \times 10^{-3} \mathrm{M}\right)$, carboplatin, CAP $\left(1 \times 10^{-10}-3.5 \times 10^{-4} \mathrm{M}\right)$ and cyclophosphamide, CPA $\left(1 \times 10^{-11}-1 \times 10^{-5} \mathrm{M}\right)$. Cell proliferation was monitored using an MTT assay.

results are in line with other several studies that have shown the capability of Nar to stimulate apoptosis in different cancer cell lines [24,31,38,39]. Moreover, emerging evidence from literature has also demonstrated that the anti-proliferative effect of natural products is associated with apoptosis induction [40-42]. Again, the results from this study are in line with these findings. Taken together, dysregulation of the cell cycle mechanism and the induction of cancer cell apoptosis are recognized as an important goal of cancer therapy.
It is known that PI3K and its downstream substrate Akt have a role in apoptosis [43]. The expression of these proteins was examined, identifying dose-dependent reductions of PI3K and phospho-Akt in both colorectal and breast cancer cell lines. Total Akt protein levels remained unchanged throughout the course of the experiment. These results are in agreement with those documented from other studies in other malignancies [42,44].

The PI3K/Akt signaling pathway is influential in the regulation of cell survival due to the activation of anti- 
Table 2 Percentage mean cytotoxicities of DNA-acting drugs and their combinations with Nar on human colorectal and breast cancer cells

\begin{tabular}{|c|c|c|c|c|}
\hline \multirow{2}{*}{$\begin{array}{l}\text { Treatment with DNA-acting drugs } \\
\text { and their combinations with Nar }\end{array}$} & \multicolumn{2}{|c|}{ Percentage mean cytotoxicity ${ }^{a}$} & \multicolumn{2}{|c|}{ Fold increase in therapeutic efficac) } \\
\hline & SW837 & HTB132 & SW837 & HTB132 \\
\hline $5 \mathrm{FU}\left(1 \times 10^{-10}-1 \times 10^{-3} \mathrm{M}\right)$ & $8 \pm 1.0$ & $54 \pm 0.42$ & & \\
\hline $5 \mathrm{FU}\left(1 \times 10^{-10}-1 \times 10^{-3} \mathrm{M}\right)+\operatorname{Nar}(0.5 \mathrm{mM})$ & $50 \pm 1.6$ & $96 \pm 0.44$ & 6.25 & 1.7 \\
\hline $\mathrm{CIP}\left(1 \times 10^{-10}-1 \times 10^{-3} \mathrm{M}\right)$ & $3 \pm 0.8$ & $49 \pm 0.5$ & & \\
\hline $\mathrm{CIP}\left(1 \times 10^{-10}-1 \times 10^{-3} \mathrm{M}\right)+\operatorname{Nar}(0.5 \mathrm{mM})$ & $39 \pm 2$ & $80 \pm 0.6$ & 13 & 1.63 \\
\hline $\mathrm{CAP}\left(1 \times 10^{-10}-1 \times 10^{-3} \mathrm{M}\right)$ & $9 \pm 2$ & $40 \pm 2$ & & \\
\hline $\operatorname{CAP}\left(1 \times 10^{-10}-1 \times 10^{-3} \mathrm{M}\right)+\operatorname{Nar}(0.5 \mathrm{mM})$ & $27 \pm 1.0$ & $83 \pm 1.5$ & 3 & 2.1 \\
\hline $\mathrm{CPT}\left(1 \times 10^{-10}-1 \times 10^{-3} \mathrm{M}\right)$ & $8 \pm 1.1$ & $60 \pm 2.2$ & & \\
\hline CPT $\left(1 \times 10^{-10}-1 \times 10^{-3} \mathrm{M}\right)+\operatorname{Nar}(0.5 \mathrm{mM})$ & $50 \pm 2.6$ & $95 \pm 0.3$ & 6.25 & 1.58 \\
\hline $\operatorname{DOX}\left(1 \times 10^{-10}-1 \times 10^{-3} \mathrm{M}\right)$ & $6 \pm 1.3$ & $54 \pm 1.3$ & & \\
\hline $\operatorname{DOX}\left(1 \times 10^{-10}-1 \times 10^{-3} \mathrm{M}\right)+\operatorname{Nar}(0.5 \mathrm{mM})$ & $41 \pm 3$ & $84 \pm 0.6$ & 6.83 & 1.56 \\
\hline $\mathrm{CPA}\left(1 \times 10^{-11}-1 \times 10^{-4} \mathrm{M}\right)$ & $15 \pm 2.6$ & $44 \pm 0.8$ & & \\
\hline CPA $(1 \times 10-11-1 \times 10-4 \mathrm{M})+\operatorname{Nar}(0.5 \mathrm{mM})$ & $47 \pm 1.1$ & $88 \pm 1$ & 3.13 & 2 \\
\hline $\operatorname{ETP}\left(1 \times 10^{-10}-1 \times 10^{-3} \mathrm{M}\right)$ & $10 \pm 2$ & $51 \pm 1.6$ & & \\
\hline $\operatorname{ETP}\left(1 \times 10^{-10}-1 \times 10^{-3} \mathrm{M}\right)+\operatorname{Nar}(0.5 \mathrm{mM})$ & $57 \pm 0.6$ & $83 \pm 0.93$ & 5.7 & 1.63 \\
\hline $\operatorname{ELP}\left(1 \times 10^{-11}-1 \times 10^{-4} \mathrm{M}\right)$ & $23 \pm 2.5$ & $51 \pm 1.6$ & & \\
\hline $\operatorname{ELP}\left(1 \times 10^{-11}-1 \times 10^{-4} \mathrm{M}\right)+\operatorname{Nar}(0.5 \mathrm{mM})$ & $70 \pm 1.8$ & $93 \pm 0.6$ & 3.04 & 1.82 \\
\hline
\end{tabular}

a The data are based on the mean of absorbance from 3 independent experiments.

b ${ }^{\text {c }} P$-values of the combined treatments with DNA-acting drugs and Nar versus DNA-acting drugs $=0.0001$.

apoptotic downstream effectors [45] and phosphorylationdependent inhibition of pro-apoptotic signals such as Bad, caspase-9, and the family of Forkhead transcription factors [46]. Akt inhibition results in the upregulation of FasL expression in vascular smooth muscle cells and Hela cells [47]. Downregulation of Akt leads to a decrease in the phosphorylation of the endogenous Forkhead factors and its location to the nucleus. It impairs the induction of FasL promoter [46]. In addition, Akt promotes cell survival via NF- $\kappa B$ activation [48]. The present study sought to determine the effects of PI3K/Akt on Nar-induced apoptosis. The results showed that Nar down-regulated the PI3K/ Akt signaling pathway and that the PI3K/Akt pathway inhibition may increase Nar-induced apoptosis. These data are in accord with those reported in other studies in other types of malignancies $[29,42,44]$

$\mathrm{NF}-\mathrm{\kappa B}$ participates in multiple steps in cancer cell resistance to chemical and radiation therapies [18] highlighting its significance as a target in cancer treatment and chemoprevention [49]. We therefore explored this transcription factor as a target for the treatment of human colorectal and breast cancer cells by using Nar. Our results indicate that NF- $\mathrm{KB}$ is constitutively active in human breast and colorectal cancer cell lines examined and that Nar downregulated the nuclear pool, or active form, of NF- $\mathrm{kB}$ and suppressed $I_{\kappa} B \alpha$ phosphorylation and the expression of the NF- $\kappa \mathrm{B}$-regulated gene products $\mathrm{I} \kappa \mathrm{B} \alpha, \mathrm{Bcl} 2$ and $\mathrm{c}-\mathrm{IAP}-$ 2. This led to the suppression of proliferation and induction of apoptosis. Nar appears to suppress IKK activation (under investigation) which leads to inhibition of I $\mathrm{B} \alpha$ phosphorylation, as reported in the current study abrogating $I \kappa B \alpha$ degradation by ubiquitin-proteasome pathway.

An imbalance between cell proliferation and cell death due to cell cycle disruption will lead to cancer development. Thus, the cell cycle could serve as a target for anticancer agents to inhibit the uncontrolled proliferation of cancer cells and initiate their apoptosis [50-52]. In the present study, expression of cell cycle-regulatory genes was assessed to understand the underlying molecular mechanisms of Nar anticancer and apoptosis-inducing effects. Human colorectal and breast cancer cells treated with Nar exhibited a marked down-regulation in the mRNA of genes related to cell cycle control, including Cdk4, Cdk6 and Cdk7. However, the same treatment resulted in the upregulation of cell cycle-dependent kinase inhibitor genes, $p 18, p 19$ and $p 21$. These results are consistent with the findings in other types of malignancies [31,42]. Increased levels of p18, p19, p21 and maintenance of the key cell cycle regulatory proteins that counter proliferation signals, eventually leading to apoptosis, are possible mechanisms of colorectal and breast cancer cell death induced by Nar.

Apoptosis is a cell suicide mechanism that is frequently dysregulated in oncogenesis. Generally, apoptosis occurs via two fundamental pathways: 1) the mitochondrial or 
intrinsic pathway and 2) the death receptor or extrinsic pathway [53]. The intrinsic pathway is triggered by the release of mitochondrial proteins, such as cytochrome $c$, which bind to Apaf- 1 and procaspase- 9 in an ATPdependent manner to form the apoptosome [54]. The apoptosome activates caspase-9, thereby initiating the apoptotic caspase cascade [55]. Conversely, the extrinsic pathway is initiated by the interaction of ligands with their respective death receptors, sequentially leading to cleavage of the initiator, caspase-8. Active caspase- 8 cleaves the executioner procaspase-3, resulting in apoptosis [56]. The apical proteases in the intrinsic and extrinsic pathways are caspase- 9 and caspase- 8 , respectively. Activated caspase- 8 and caspase- 9 further initiate activation of the caspase cascade, leading to biochemical and morphological changes associated with apoptosis [57]. Caspase-3 is a well-known downstream adaptor caspase that is proteolytically activated by caspase- 9 or caspase- 8 via mitochondrial or cell death receptor signaling pathways [58]. Thus, caspases have been shown to be activated during apoptosis in many cells and play critical roles in both the initiation and execution of apoptosis [59]. To characterize the apoptotic mechanisms induced by Nar, the expression of pro- and anti-apoptotic proteins were assessed. The human colorectal and breast cancer cells exposed to Nar displayed a marked up-regulation in the mRNA expression of proapoptotic genes including Caspases-3, 7, 8, and 9, Bak, $A I F$ and Bax. Meanwhile, the mRNA expression of the anti-apoptotic genes including $B c l 2, x-I A P$ and $c-I A P-2$ was differentially down-regulated in both colorectal and breast cancer cells. These results are in agreement with those findings in other malignancies $[29,31,41,42,60]$.

Numerous studies have demonstrated that the Bcl-2 family significantly regulates apoptosis, either as an activator (Bax) or as an inhibitor (Bcl2) [61]. Bcl2 is a known anti-apoptotic protein that is frequently examined for potential clinical use as a prognostic biomarker in cancer, and its overexpression is associated with resistance to cytotoxic drugs such as cisplatin and 5-fluorouracil. In addition, studies have shown that aberrant expression of this protein facilitates tumor progression [62].

The results presented here demonstrated that Narinduced apoptosis relates to augmented levels of Bax and down-regulation of $\mathrm{Bcl} 2$ inducing mitochondrial dysfunction and leading to apoptosis of colorectal and breast cancer cells.

Bax is an essential mitochondrial-mediated apoptosis activator, as its insertion in the mitochondrial membrane results in the release of cytochrome $c$ into the cytosol leading to the activation of caspases and committing the cells to apoptosis [63].

The caspase family, aspartate-specific cysteine proteases, also plays a critical role in regulating apoptosis. Caspase signaling is initiated and propagated by proteolytic autocatalysis and by the cleavage of downstream caspases and substrates such as PARP and lamin A [64]. In particular, caspase- 3 is one of the key executioners of apoptosis because it is either partially or totally responsible for the proteolytic cleavage of many key proteins that are important for cell viability [65]. Caspase-9 is an initiator caspase in the apoptotic process, and its function is to activate the effector caspases 6, 7 and 3 [66]. Caspase-independent pathways are involved in mitochondrial dysfunction leading to release of AIF and Endo $G$ from mitochondria and apoptosis [66]. The results from real-time PCR also showed that Nat promoted AIF expression in both colorectal and breast cancer cells, suggesting that Nar-induced apoptosis also involves caspase-independent mechanisms.

The upregulation of pro-apoptotic genes in conjunction with the down-regulation of anti-apoptotic genes in colorectal and breast cancer cells treated with Nar may serve to shift the balance from pro-survival to proapoptotic. Nar treatment, thus, may lower the threshold of colorectal and breast cancer cells to pro-death signals, thereby accounting for its anticancer effects. It is well established that agents capable of inducing apoptosis as a mode of cell death are good anticancer candidates [67]. Therefore, Nar is a potential anticancer candidate that is believed to selectively induce apoptosis in cancer cells.

Chemotherapy is one of the main strategies to eliminate residual cancer cells and prevent metastasis after surgery or radiotherapy. The survival period and quality of life of cancer patients have improved with the advent of novel chemotherapeutic agents, such as docetaxel [68]. However, patients continue to suffer various toxic effects including myelosuppression, vomiting and hypersensitivity reactions. Meanwhile, the development of drug resistance continues to threaten patient prognosis [69]. Chemotherapy may also sometimes aggravate cancer progress and lead to patient death [70]. Recently, the concept "to live in harmony with the tumor" has been proposed. This notion has become a new direction in cancer research [71]. In the present study, Nar markedly reduced the apoptotic threshold of both colorectal and breast cancer cells. These results encouraged us to evaluate the potential of Nar to enhance the sensitivity of colorectal and breast cancer cells to DNA-damaging drugs. The results clearly indicated that simultaneous treatment with Nar and DNA-acting drugs exhibited substantially higher cytotoxicity on both colorectal and breast cancer cells compared with a single treatment with a DNA-acting drug. Nar potentiates the chemosensitivity of tested cancer cells in a drug- and cancertype dependent manner (Figures 6, 7, Table 2). These results are in line with findings in other malignancies $[31,72,73]$. 
Thus, Nar has the potential to be a useful adjunct to improve the effectiveness of chemotherapeutic agents in the treatment of human cancers. Nar potentiates the anticancer effects of DNA-acting drugs by activating pro-apoptotic signaling, negating survival signaling, and attenuating their side effects. Testing this strategy with a larger number of cancer cell lines would increase the value of this study. In addition, in vivo studies using animal models are necessary to confirm the validity of this combination strategy for the treatment of colorectal and breast cancers and possibly other types of cancers.

\section{Conclusions}

The findings of the present study have important clinical implications. This study demonstrated that Nar induces apoptosis and potentiates the sensitivity of both colorectal and breast cancer cells through multifactorial mechanisms including cell cycle arrest, up-regulation of the expression of pro-apoptotic genes, down-regulation of anti-apoptotic genes and inhibition of pro-survival signaling pathways. Nar therefore displays promise as a pro-apoptotic factor that may benefit colorectal and breast therapy. However, further studies should be conducted in appropriate animal models of cancer, and ultimately, human cancer prevention trials should be performed.

\section{Competing interests}

The authors declare that they have no competing interests.

\section{Authors' contributions}

MA designed the study, analyzed data, and wrote manuscript; MA and EQ performed all the biological studies; KO and EQ conducted isolation and identification of Nar, $\mathrm{KO}$ assisted in writing and editing the manuscript; RA and MA performed the flow cytometry analysis. All authors read and approved the final manuscript

\section{Acknowledgments}

This work was supported by Kuwait University, Research Grant No. [YS06-10]. The authors would like to acknowledge General Facility Kuwait University Project No. [SRUL02/13] for densitometry scanning of western blots.

\section{Author details \\ ${ }^{1}$ Molecular Biology Program, Department of Biological Sciences, Faculty of Science, Kuwait University, Safat 13060, Kuwait. ${ }^{2}$ Department of Pharmaceutical Chemistry, Faculty of Pharmacy, Kuwait University, Safat 13110, Kuwait. ${ }^{3}$ Department of Microbiology and Immunology, Faculty of Medicine, Kuwait University, Safat 13110, Kuwait.}

Received: 29 June 2014 Accepted: 6 April 2015

Published online: 24 April 2015

\section{References}

1. World Health Organization. The global burden of disease: 2004 update. Geneva: World Health Organization; 2008.

2. Jemal A, Bray F, Center MM, Ferlay J, Ward E, Forman D. Global cancer statistics. CA Cancer J Clin. 2011;61:69-90.

3. El-Basmy A, Al-Mohannadi A, Al-Awadi A. Some epidemiological measures of cancer in Kuwait: national cancer registry data from 2000-2009. Asian Pac J Cancer Prev. 2012;13:3113-8.

4. Carvalho M, Jeronimo C, Valentao P, Andrade PB, Silva BM. Green tea: a promising anticancer agent for renal cell carcinoma. Food Chem. 2010;122:49-54
5. Tan AC, Konczak I, Sze DM, Ramzan I. Molecular pathways for cancer chemoprevention by dietary phytochemicals. Nutr Cancer. 2012;63:495-505.

6. Wahle KW, Brown I, Rotondo D, Heys SD. Plant phenolics in the prevention and treatment of cancer. Adv Exp Med Bio. 2011;698:36-51.

7. Clere N, Faure S, Martinez MC, Andriantsitohaina R. Anticancer properties of flavonoids: role in various stages of carcinogenesis. Cardiovasc Hematol Agents Med Chem. 2011;9:62-77.

8. Yoshida H, Takamura N, Shuto T, Orgata K, Tokunaga J, Kawa K, et al. The citrus flavonoids hesperetin and naringenin block the lipolytic actions of TNFa in mouse adipocytes. Biochem Biophs Res Commun. 2010;2010:728-32.

9. Arul D, Subramanian P. Inhibitory effect of naringenin (citrus flavonone) on $\mathrm{N}$-nitrosodiethylamine induced hepatocarcinogenesis in rats. Biochem Biophs Res Commun. 2013;434:203-9.

10. Hendawy SF, Ezz El-din A, Aziz EE, Omer EA. Productivity and oil quality of Thymus vulgaris under organic fertilization condition. Ozean Journal of Applied Sciences. 2010;3:203-16.

11. El-Nekeety AA, Mohamed SR, Hathout AS, Hassan NS, Aly SE, Abdel-Wahhab MS. Antioxidant properties of Thymus vulgaris oil against aflatoxin-induced oxidative stress in male rats. Toxicol. 2011;57:984-91.

12. Stahl-Biskup E, Saez F. Thyme. London: Taylor and Francis; 2002.

13. Amirghofran A, Karimi MH. Cytotoxicity of Thymus vulgaris, Achillea millefolium and Thuja orientalis on growing cell lines. MJIRI. 2001;15:149-54.

14. Mosmann T. Rapid colorimetric assay for cellular growth and survival: application to proliferation and cytotoxicity assays. J Immunol Methods. 1983;65:55-63.

15. Abaza MSI, Bahman A, Al-Attiyah R. Valproic acid, an antiepileptic drug with histone deacetylase inhibition activity, and proteasome inhibitors exert synergistic antiproliferative, proapoptotic and chemosensitizing effects in human colorectal cancer cells: underlying molecular mechanisms. Int J Mol Med. 2014;34:513-32

16. Fan XM, Wong BC, Wang WP, Zhou XM, Cho CH, Yuen ST, et al. Inhibition of proteasome function induced apoptosis in gastric cancer. Int I Cancer. 2001;93:481-8

17. Abaza MSI. Augmentation of the anticancer effects of proteasome inhibitors by combination with sodium butyrate in human colorectal cancer cells. Exp Ther Med. 2010;1:675-93.

18. Chen W, Li Z, Bai L, Lin Y. NFkB in lung cancer, a carcinogenesis mediator and a prevention and therapy target. Front Biosci. 2011;16:1172-85.

19. Kulik G, Klippel A, Weber MJ. Antiapoptotic signaling by the insulin-like growth factor receptor, phosphatidylinositol 3-kinase, and Akt. Mol Cell Biol. 1997;17:1595-606

20. Malumbres M, Barbacid M. Mammalian cyclin-dependent kinases. Trends Biochem Sci. 2005:30:630-41.

21. Borner C. The Bcl2 protein family; sensor and checkpoints for life-or-death decisions. Mol Immunol. 2003:39:615-47.

22. Cragg GM, Newman DJ, Snader KM. Natural products in drug discovery and development. J Nat Prod. 1997:60:52-60.

23. Kandaswami C, Lee MT. The antitumor activities of flavonoids. In Vivo. 2005;19:895-909.

24. Jin CY, Park C, Hwang HJ, Kim GY, Choi BT, Kim WJ, et al. Naringenin up-regulates the expression of death receptor 5 and enhances TRAlL-induced apoptosis in human lung cancer A549 cells. Mol Nutr Food Res. 2010;55:300-9.

25. Kanno S, Tomizawa A, Ohtake T, Koiwai K, Ujibe M, Ishikawa M. Naringenin-induced apoptosis via activation of NF-KB and necrosis involving the loss of ATP in human promyeloleukemia HL-60 cells. Toxicol Lett. 2006;166:131-9.

26. Wang BD, Yang ZY, Wang Q, Cai TK, Crewdson P. Synthesis, characterization, cytotoxic activities, and DNA-binding properties of the La (III) complex with naringenin Schiff-base. Bioorg Med Chem. 2006;14:1880-8.

27. Jain R, Mitta M. Naringenin, a flavanone from the stem of Nyctanthes Arbotristis Linn. International Journal of Biology, Pharmacy and Allied Sciences. 2012;1:964-72.

28. Lee I, Bae J, Kim T, Kwon O, Kim TH. polyphenolic constituents from the aerial parts of Thymus quinquecosttus var. japonica collected on Ulleung Island. J Korean Soc Appl Biol Chem. 2011;54:811-6.

29. Arul D, Subramanian P. Naringenin (citrus flavonone) induces growth inhibition, cell cycle arrest and apoptosis in human hepatocellular carcinoma cells. Pathol Oncol Res. 2013;19:763-70.

30. Frydoonfar HR, McGrath DR, Spigelman AD. The variable effect on proliferation of a colon cancer cell line by the citrus fruit flavonoid naringenin. Colorectal Dis. 2003;5:149-52. 
31. Kim JH, Kang JW, Kim MS, Bak Y, Park YS, Jung KY, et al. The apoptotic effects of the flavonoids N101-2 in human cervical cancer cells. Toxicol in Vitro. 2012;26:67-73.

32. Sulfikkarali N, Krishnakumar N, Manoharan S, Nirmal RM. Chemopreventive efficacy of naringenin-loaded nanoparticles in 7, 12-dimethylbenz (a) anthracene induced experimental oral carcinogenesis. Pathol Oncol Res. 2013;19:287-96.

33. Krishnakumar N, Sulfikkarali N, Manoharan S, Nirmal RM. Screening of chemopreventive effect of naringenin-loaded nanoparticles in DMBA-induced hamster buccal pouch carcinogenesis by FT-IR spectroscopy. Mol Cell Biochem. 2013;382:27-36.

34. Dickson MA, Schwartz GK. Development of cell cycle inhibitors for cancer therapy. Curr Oncol. 2009;16:36-43.

35. Adhami VM, Aziz MH, Reagan-Shaw SR, Nihl M, Mukhtar H, Ahmad N. Sanguinarine causes cell cycle blockade and apoptosis of human prostate carcinoma cells via modulation of cyclin kinase inhibitor-cyclin-cyclin-dependent kinase machinery. Mol Cancer Ther. 2004;3:933-40.

36. Kögel D, Fulda S, Mittelbronn M. Therapeutic exploitation of apoptosis and autophagy for glioblastoma. Anticancer Agents Med Chem. 2010;10:438-49.

37. McConkey DJ. Therapy-induced apoptosis in primary tumors. Adv Exp Med Biol. 2007:608:31-51.

38. Tan M, Zhu J, Pan Y, Chen Z, Liang H, Liu H, et al. Synthesis, cytotoxic activity, and DNA binding properties of copper (II) complexes with hesperetin, naringenin, and apigenin. Bioinorganic Chem Appl. 2009;2009:347872-80.

39. Sabarinathan D, Mahalakshmi P, Vanisree AJ. Naringenin promote apoptosis in cerebrally implanted C6 glioma cells. Mol Cell Biochem. 2010;345:215-22.

40. Zhong Z, Chen X, Tan W, Xu Z, Zhou K, Wu T, et al. Germacrone inhibits the proliferation of breast cancer cell by inducing cell cycle arrest and promoting apoptosis. Eur J Pharmacol. 2011;667:50-5.

41. Park HS, Kim GY, Nam TJ, Deuk Kim N, Hyun Choi Y. Antiproliferative activity of fucoidan was associated with the induction of apoptosis and autophagy in AGS human gastric cells. J Food Sci. 2011;26:77-83.

42. Bak Y, Kim H, Kang JW, Lee DH, Kim MS, Jung KY, et al. A synthetic naringenin derivative, 5-hydroxy-7, 4-diacetyloxyflavanone-N-phenylhydrazone (N101-43), induces apoptosis through up-regulation of Fas/FasL expression and inhibition of PI3K/Akt signaling pathways in non-small-cell lung cancer cells. J Agric Food Chem. 2011;59:10286-97.

43. Franke TF, Yang SL, Chan TO, Datta K, Kazlauskas A, Morrison DK, et al. The protein kinase encoded by the Akt proto-oncogene is a target of the PDGF-activated phosphatidylinositol 3-kinase. Cell. 1995;81:727-36.

44. Park JH, Jin CY, Lee BK, Kim GY, Lee BK, Kim GY, et al. Naringenin induces apoptosis through downregulation of Akt and caspase-3 activation in human leukemia THP-1 cells. Food Chem Toxicol. 2008;46:3684-90.

45. Datta SR, Brunet A, Greenberg ME. Cellular survival: a play in three Akts. Genes Dev. 1999;13:2905-27.

46. Ciechomska I, Pyrzynska B, Razmierczak P, Kaminska B. Inhibition of Akt kinase signaling and activation of Forkhead are indispensable for upregulation of FasL expression in apoptosis of glioma cells. Oncogene. 2003;22:7617-27

47. Uriarte SM, Joshi-Barve S, Song Z, Sahoo R, Gobejishvili L. Akt inhibition up-regulates FasL, downregulates c-FLIPs and induces caspase-8-dependent cell death in Jurkat T Iymphocytes. Cell Death Differ. 2005;12:233-42.

48. Madrid LV, Mayo MW, Reuther JY, Baldwin Jr AS. Akt stimulates the transactivation potential of the RelA/p65 subunit of NF-KB through utilization of the $1-k B$ kinase and activation of the mitogen-activated protein kinase p38. J Biol Chem. 2001;276:18934-40.

49. Nakagawa Y, Sedukhina AS, Okamoto N, Nagasawa S, Suzuki N, Ohta T, et al. NF-KB signaling mediates acquired resistance after PARP inhibition. Oncotarget: Advance Publications; 2015

50. Chu IM, Hengst L, Slingerland JM. The Cdk inhibitor p27 in human cancer: prognostic potential and relevance to anticancer therapy. Nat Rev Cancer. 2008;8:253-67.

51. Tanse S, Ikenishi A, Okayama H, Iwamoto N, Nakayama Kl, Takeuchi T. CDK inhibitors, p21(Cip) and p27 (Kip1), participate in cell cycle exit of mammalian cardiomyocytes. Biochem Biophys Res Commun. 2014;443:1105-9.

52. Tateishi Y, Matsumoto A, Kanie T, Hara E, Nakayama K, Nakayama Kl. Development of mice without Cip/Kip CDK inhibitors. Biochem Biophys Res Commun. 2012:427:285-92
53. Yoon JH, Gores GJ. Death receptors-mediated apoptosis and the liver. J Hepatol. 2002;37:400-10.

54. Mignotte B, Vayssiere JL. Mitochondria and apoptosis. Eur J Biochem. 1998:252:1-15

55. Sun SY, Hail Jr N, Lotan R. Apoptosis as a novel target for cancer chemoprevention. J Natl Cancer Inst. 2004;96:662-72.

56. Scaffidi C, Fulda S, Strinivasan A, Friesen C, Tomaselli KJ, Debatin KM, et al. Two CD95 (APO1/Fas) signaling pathways. EMBO Journal. 1998;17:1675-87.

57. Tepper CG, Seldin MF, Mudryj M. Fas-mediated apoptosis of proliferating, transiently growth-arrested, and senescent normal human fibroblasts. Exp Cell Res. 2000;260:9-19.

58. Hsu HF, Houng JY, Kuo CF, Tssao N, Wu YC. Glossogin, a novel phenylpropanoid from Glossogyne tenuifolia induced apoptosis in A549 lung cancer cells. Food Chem Toxicol. 2008:46:3785-91.

59. Liu ZB, Hou YF, Min-Dong MD, Di GH, Wu J, Shen ZZ, et al. PA-MSHA inhibits proliferation and induces apoptosis through up-regulation and activation of caspases in the human breast cancer cell lines. J Cell Biochem. 2009;108:195-206.

60. Li Y, Wang Y, Wang S, Gao Y, Zhang X, Lu C. Oridonin phosphate-induced autophagy effectively enhances cell apoptosis of human breast cancer cells. Med Oncol. 2015;32:365.

61. Dlugosz PJ, Billen LP, Annis MG, Zhu W, Zhang Z, Lin J, et al. Bcl-2 changes conformation to inhibit Bax oligomerization. EMBO J. 2006;25:2287-96.

62. Kelly PN, Strasser A. The role of BCl-2 and its pro-survival relatives in tumorigenesis and cancer therapy. Cell Death Differ. 2011;18:1414-24.

63. Martinou JC, Youle RJ. Mitochondria in apoptosis: BCl-2 family members and mitochondria dynamics. Dev Cell. 2011;21:92-101.

64. Hengartner MO. The Biochemistry of apoptosis. Nature. 2000:407:770-8.

65. Oliver FJ, de La Rolli V, Ruiz-Ruiz MC, de Murcia G, Murcia JM. Importance of poly (ADP-ribose) polymerase and its cleavage in apoptosis. Lesson from an uncleavable mutant. J Biol Chem. 1998:273:33533-9.

66. Wu PP, Kuo SC, Huang WW, Yang JS, Lai KC, Chen HJ, et al. (-)-epigallocatechin gallate induced apoptosis in human adrenal cancer $\mathrm{NCl}-\mathrm{H} 295$ cells through caspase-dependent and caspase-independent pathway. Anticancer Res. 2009;29:1435-42.

67. Schmidt M, Betti G, Hensel A. Saffron in phytotherapy: Pharmacology and clinical uses. Wiener Medizinische Wochenschrift. 2007;157:315-9.

68. Wang QW, Lu HL, Song CC, Liu H, Xu CG. Radio-sensitivity of human colon cancer cell enhanced by immune-liposomal docetaxel. World J Gastroenterol. 2005;14:4003-7.

69. Cost MIS, Boldrini JL. Conflicting objectives in chemotherapy with drug resistance. Bull Math Biol. 1997:59:707-24

70. Martin IC, Smith N, Cooper H. Deaths following chemotherapy-lesson to be learnt. Br J Oral Maxillofac Surg. 2009;47:e51.

71. Towsley GL, Beck SL, Watkins JF. Learning to live with it: coping with the transition to cancer survivorship in older adults. Journal of Aging Studies. 2007;21:93-106.

72. Zhang FY, Du GJ, Zhang L, Zhang CL, Lu WL, Liang W. Naringenin enhances the anti-tumor effect of doxorubicin through selectively inhibiting the activity of multidrug resistance-associated proteins but not P-glycoprotein. Pharm Res. 2009;26:914-25.

73. Veeraraghavan S, Aravindan S, Natarajan M, Awasthi V, Herman S, Aravindan N. Neem leaf extract induces radio-sensitization in human neuroblastoma xenograft through modulation of apoptotic pathway. Anticancer Res. 2011;31:161-70.

\section{Submit your next manuscript to BioMed Central and take full advantage of:}

- Convenient online submission

- Thorough peer review

- No space constraints or color figure charges

- Immediate publication on acceptance

- Inclusion in PubMed, CAS, Scopus and Google Scholar

- Research which is freely available for redistribution 